\title{
Outburst floods in China: a review
}

Weiming Liu ${ }^{\text {a, b, d* }}$, Paul A. Carling ${ }^{\mathrm{c}}$, Kaiheng Hu${ }^{\mathrm{a}}$, Hao Wang ${ }^{\mathrm{e}}$, Zhen Zhou ${ }^{\mathrm{f}}$, Liqin Zhou ${ }^{\mathrm{a}}$, Dingzhu Liu ${ }^{\mathrm{a}}$, Zhongping Lai ${ }^{\mathrm{g}}$, Xinbao Zhang ${ }^{\mathrm{a}}$

${ }^{a}$ CAS Key Laboratory of Mountain Hazards and Surface Process, Institute of Mountain Hazards and Environment, Chinese Academy of Sciences, Chengdu 610041, China

${ }^{b}$ The State Key Laboratory of Geohazard Prevention and Geoenvironment Protection (Chengdu University of Technology), Chengdu 610059, China

${ }^{c}$ Geography and Environment, University of Southampton, Southampton SO17 1BJ, UK

${ }^{d}$ China-Pakistan Earth Science Joint research Center, Islamabad, Islamic Republic of Pakistan

${ }^{e}$ CAS Center for Excellence in Tibetan Plateau Earth Sciences, Beijing 100101, China

${ }^{f}$ Faculty of Geosciences and Environmental, Engineering of Southwest Jiaotong University, Chengdu 611756, China

${ }^{g}$ Institute of Marine Science, Shantou University, Shantou, Guangdong Province, 515063, China

*Corresponding author: Liuwm@imde.ac.cn (W. Liu)

Abstract: Outburst floods can have disastrous impacts on people, and are an important driving force in landscape change and have been studied widely on Earth. In China, although outburst floods have occurred frequently, they have been relatively little systematic studied. Here, we review outburst floods in China in terms of the characteristics, distribution, causes of dams and outburst floods. In terms of natural dams, landslides accounted for the majority 
(287 cases), followed by moraine dams (33 cases), which are mainly found on and around the Tibetan Plateau, and although other types (such as glacier and volcanic dams) were historically rare, many examples may be preserved in the geologic record. In addition, there have been thousands of outburst floods from artificial-constructed dams, the majority of which were from small earth dams. The largest reliably recorded peak discharge for an outburst flood was $1.24 \times 10^{5} \mathrm{~m}^{3} / \mathrm{s}$, which occurred in Yigong, Tibet. The peak discharge of the 1975 Banqiao collapse was $7.9 \times 10^{4} \mathrm{~m}^{3} / \mathrm{s}$, was the largest outburst flood of man-made dam. Our recent investigations on the Yarlung Tsangpo in Southeast Tibet have identified gravel deposits that probably record megafloods and offer great potential for paleoflood analysis. Key words: Outburst floods; Natural dams; Artificial dams; Tibetan Plateau; Gravel bars

\section{Introduction}

Outburst floods refer to the floods caused by a sudden release of much water, have led most of the largest lethal floods on Earth (Baker et al., 2013; O'Connor et al., 2013), are often regarded to be synonymous with megafloods. A variety of geological processes can lead to outburst floods. Following O'Connor et al. (2013), outburst floods could be divided into three categories: (1) valley blockages, including natural processes such as landslides, mudslides, glaciers surges and lava flows and constructed dams; (2) natural closed basins filled with water, such as tectonic basins, ice sheet basins, moraine-rimmed basins; (3) groundwater bodies trapped under rock strata or ice, such as underground lakes on Mars and subglacial lakes in the Antarctic. 
recorded outburst flooding in China, in the book of Shu king (Yang, 1993), was on the Chengdu plain, thought to have originated from Yu Mountain (Shiyu Mountain) during the period of King Duyu (c.11 ${ }^{\text {th }}$ century BCE) (Jia, 2013). More than 30 historical records of "landslides" or "blocking" are included in official history books (Tab. S1). The earliest official record, dating to 586 BC, is for a site in what is Shanxi Province today and states "The landslide in Liang mountain caused the river to not flow for three days" (Du, 1987). Despite their long recognition, there has been little systematic research of outburst floods in China. With the construction of many water conservancy projects after the foundation of the People's Republic of China in 1949, the collapse of artificial dams became a problem and the first systematic research was initiated in response (Ye, 1977). Later, research on moraine dams was triggered after concern was raised about increasing glacial lake outbursts in Tibet (Xu and Feng, 1988). Outburst floods associated with landslide dams are the most widespread damage and have had the greatest impact in terms of loss of life and damage. Flooding of the Yigong landslide dam lake in 2000 caused widespread concern (Shang et al., 2003), and the 1786 dam break flood on the Dadu River caused over 10,000 deaths (Dai et al., 2005).

Many rivers in China flow through mountainous areas with conditions favorable for river blocking. Outburst floods are especially prevalent in the margins of the Tibetan Plateau due to high relief, narrow river gorges and threshold hillslopes (Fig. 1). A recent global outburst flood review contained few cases in China (O'Connor et al., 2013), and a related review in China only considered moraine lake outburst floods (Xu and Feng, 1988). Reviews of landslide dams in China mainly focus on the analysis of dam stability and location, with a lack of a detailed analysis of outburst flood characteristics (Chai, 1995a; Peng and Zhang, 2012; Shi et al., 2014). Here we 
summarize the various types of outburst floods in China, assess their causes and characteristics, and identify research gaps that need to be addressed to improve outburst flooding research in the future.

\section{Methods}

The dam sources summarized in this paper are mainly from published articles, research books and historical books, and we included only them can be determined their location. We use the longitude and latitude of the middle dam to represent the position of the dam body. Although most of kinds of dam are found, that there are mainly three kinds of dams, i. e. landslide dam, moraine dam and artificial dam (Fig. 2). Among them, there are 287 landslide dams, 33 moraine dams, 55 artificial dams, 5 glacier dams, 1 volcanogenic dams, and 3 rock-bound dams (Tab. 1).

After analyzing the dams, we analyzed the outburst floods. In order to ensure the reliability of the analysis, the outburst floods analyzed are all recorded directly, without some results reconstructed by empirical formulas. Here, the outburst floods of 11 landslide dams, 8 moraine dams, and 9 earth-fall dams are analyzed (Tab. 1).

The ultimate factors determining the magnitude of outburst floods are mainly the released water and sediment volumes, breach depth and the speed of breach development (O'Connor et al., 2013). Currently, regression relations obtained from each type of dams are still frequently used method for calculating and forecasting the peak discharge (Q). The regression methods can give no better than order-of-magnitude estimation of probable peak discharge and allow for a tradeoff between the prediction accuracy and the difficulty of complex parameter acquisition, even they do not reflect the effect of breach-formation rate on the peak discharge (Walder and O'Connor, 1997; 
Cenderelli, 2000; O'Connor et al., 2013; Froehlich, 2016). The Q is estimated based on the dam factor (Vh) (drained volume (V) times depth of breach (h)), which represents potential energy of the dammed lake, and usually produce the low average stand error (Costa, 1985; Costa and Schuster, 1988). Therefore, the collected burst floods were fitted using the Vh and Q according to dam type.

We also analyzed the behavior of the outburst floods downstream that can be collected. Flood behavior downstream of the dam mainly results from the hydrological processes at the breach, geometry of the downstream channel and erosion and deposition along the distance. Debris flows, commonly resulting from moraine and landslide dam breaches, may increase in peak flow for a specified distance downstream (usually $<10 \mathrm{~km}$ ) (O'Connor et al., 2001). In general, s mall deep lakes may have large peak discharges, but they will attenuate more rapidly downstream than large volume lakes with prolonged outflow (O’Connor and Beebee, 2009).

\section{Landslide dam outburst floods}

\subsection{Characteristics of Landslide dams in China}

The term "landslide dam" incorporates various forms of valley blockages caused by mass movements, including landslides, rockfalls and debris flows. Landslide dams are the most widely distributed and studied dam type in China (Fig. 1), with many modern and ancient landslide dams identified (Tab. S2). Although landslide dams in China have been long recorded in historical documents (Tab. S1), their systematic study only began in the 1980s. Lu (1988) examined the basic characteristics of valley-blocking landslides and identified many large-scale damming events, including landslides such as Jipazi, Zhouchangping, Tanggudong and Diexi, which are all located 
in Sichuan. Chai (1995a) compiled a catalog of 147 landslide-damming events in China. Many large landslides were formed by the 2008 Ms 8.0 Wenchuan earthquake, resulting in 256 landslide dammed lakes (Cui et al., 2009), of which the Tangjiashan dammed lake is the largest and most threatening. Before its artificial drainage, Tangjiashan lake reached an elevation of $740 \mathrm{~m}$ and a volume of $3.15 \times 10^{8} / \mathrm{m}^{3}$ (Cui et al., 2011). Shi et al. (2014) identified 758 cases of landslide dams and analyzed their distribution, formation, life span, failure, height, and storage capacity. These studies focus on dam stability factors, with few studies on the characteristics and dynamics of outburst floods.

For this review, we examined records of 287 landslide dams in China (Fig. 1; Tab. S2). Although this compilation characterizes far fewer than the cases of Shi et al. (2014), it includes detailed information on the location of the landslide dams. Our compilation only includes 16 of the large and well recorded landslide dams resulting from the 2008 Wenchuan earthquake. Our catalog also omits many dam and outburst phenomena described only in historical documents (Tab. S1) as it is difficult to determine their precise location.

The duration of landslide dams varies widely, and most of the landslide dams in our catalog were short-lived: of the 184 cases where we could judge the interval between formation and outburst, $10 \%$ breached within 1 day and $31 \%$ in 10 days. Most of the landslide blocking events in China were along on the edge of the Tibetan Plateau (Fig. 1), with Taiwan also having a relatively large number. The 41 Taiwan cases include 16 associated with typhoon Morakot in 2009 (Tab. S2). Most of the landslides cataloged are located in active fault zones that are characterized by deep valleys with steep slopes, tectonically sheared rock and narrow rivers. Typical landslide dams in the Longmenshan fault zone include Zhouchangping, Diexi, Mogangling and Tangjiashan (Fig. S1; 
Lu, 1988; Xu and Li, 2010; Wang and Shen, 2011).

We found that records of ancient landslide dams were closely related to the degree of regional research. For example, a wide range of ancient landslide dams have been identified in the Three Gorge area (Huang and $\mathrm{Xu}, 2008$ ), where researchers have made detailed investigations because of the importance of the Three Gorge Hydropower Project. Many ancient landslides and river blocking events also have been found in the upper reaches of the Yellow River, which have been extensively studied due to the construction of several large water conservancy projects such as the Longyangxia (Huang and $\mathrm{Xu}, 2008$ ). Therefore, the observed distribution of ancient landslide dams is strongly skewed and likely underestimates the actual number and extent of landslide dams.

There are two main causal factors in the formation of landslide dams, precipitation and earthquakes. Of the 161 landslide dams known causal factors recorded in China, 54\% (87 cases) were induced by precipitation, such as the Taimali Creek and Jipazi, and 38\% (61 cases) by earthquakes, such as Tangjiashan and Mogangling, accounting for $92 \%$ of the total. Other factors, such as logging, river incision and artificial excavation, accounted for only about $8 \%$, and were responsible for landslide damming at Jiguanling, Chongqing and Yanchihe, Yunnan.

Most of the landslide dams in China breached by overtopping, such as those at Diexi, in the upper reaches of the Min River (Chai et al., 1995b; Huang, 2007), and Tanggudong, in the Yalong River (Wang et al., 2012). The Yigong landslide dam, which occurred in Tibet in April 2000, blocked the Yigong Tsangpo River for two months until the lake overflowed. Initially, the overflow was small, however, the flow of water increased as material on the dam crest was eroded and eventually resulted in the dam burst (Liu et al., 2000). Landslide dams are sometimes 
destroyed by upstream flooding. For example, an aftershock of the Diexi earthquake in Sichuan in 1933 caused outburst of a lake impounded by an upstream dam, which together with heavy rains poured into Diexi dam, causing the sudden outburst of the lower lake (Chai et al., 1995b). As well forming many landslide dams, earthquakes can also damage them, as in the Dadu dam outburst flood in 1786 (Jiang, 2006). In rare cases, dams are destroyed by intense groundwater movement (Shi et al., 2014).

\subsection{Characteristics of landslide dam outburst floods}

Outburst floods potentially produce much larger peak discharges than meteorological floods at a given site. Although we cataloged 287 landslide dams, most of which had experienced outburst floods, quantitative data was available for very few of the floods. Peak flood discharge was available for only 24 landslide dam outbursts, 20 of which were directly recorded and four recovered from geomorphological or sedimentological evidence such as dammed lake deposits, dam dimensions and flood cross sections (Tab. S2). In addition, only 13 of the cases had data on both outburst depth and discharge volume (Tab. 1). Excluding two discharges based on empirical, 11 cases enable a regression analysis of the peak flood discharge versus depth of the breach, the volume of water discharged, and the product of the two. The regression equations are $\mathrm{Q}=$ $33.951 \mathrm{~h}^{1.670}, \mathrm{Q}=0.024 \mathrm{~V}^{0.701} 、 \mathrm{Q}=0.083(\mathrm{Vh})^{0.535}$ respectively and the fitted curves are shown in Fig.3 where $\mathrm{Q}$ is the peak flood discharge $\left(\mathrm{m}^{3} / \mathrm{s}\right), \mathrm{V}$ is the volume of water released from the lake $\left(\mathrm{m}^{3}\right)$, and $\mathrm{h}$ is the breach depth $(\mathrm{m})$. The coefficient of determinations $\left(\mathrm{R}^{2}\right)$ and standard errors (SE) for $\mathrm{h}, \mathrm{V}$ and $\mathrm{Vh}$ are $0.65,0.88$ and 0.88 , and $73 \%, 24 \%$ and $24 \%$ respectively. Thus, the $\mathrm{V}$ and $\mathrm{Vh}$ all produce good fit with $\mathrm{Q}$, and all data cases are within $10 \%$ error lines, which accords with 

stored water. Thus, these equations have this additional uncertainty when used for predictions.

This outcome means that for the same breach depth, the volume of released water is important for peak discharge. This conclusion is illustrated by Yigong and Diexi landslide dammed lakes which had similar outburst depths of around 58 and 50 m (Fig. 3A; Lv et al., 2002; Shi et al., 2014; Song, 2015), respectively, but the volume of water stored in the lake differed by a factor of 20 , with $2.3 \times 10^{9} \mathrm{~m}^{3}$ at Yigong (Lv et al., 2002) and only $8 \times 10^{7} \mathrm{~m}^{3}$ at Diexi (Song, 2015) (Tab. 2). Therefore, the peak discharges of Yigong and Diexi were very different, with $12.4 \times 10^{4} \mathrm{~m}^{3} / \mathrm{s}$ and $1.9 \times 10^{4}$ $\mathrm{m}^{3} / \mathrm{s}$ respectively.

The downstream flood behavior mainly depends on flow rheology, outflow hydrograph and downstream channel geometry (Wang, 1995; O'Connor et al., 2013). In general, when peak flow is large and of long duration, peak discharge attenuates gradually downstream as many of the downstream channels have been filled up before the peak arrives (O'Connor and Beebee, 2009). Wu et al. (2016) suggested that an outburst flood of $4-5 \times 10^{5} \mathrm{~m}^{3} / \mathrm{s}$ from the Jishi gorge, in the upper reaches of the Yellow River, traveled more than $2000 \mathrm{~km}$ and caused a major avulsion of the lower Yellow River. The Yigong outburst flood in 2000 not only destroyed the Tongmai bridge, which is 30 kilometers away from the dam, but also spread thousands of kilometers along the lower reaches of the Yarlung Tsangpo River (Brahmaputra River) to cover a large area in India, resulting in 94 deaths, 2.5 million homeless and disruption of roads and railways (Cheng et al., 2008a). For the three outburst flood cases in China with available data show only gradual downstream flood attenuation (Fig. 4A). In the Tanggudong and Diexi events, more than $50 \%$ of the initial peak discharge was maintained over distances of 200 and $100 \mathrm{~km}$, respectively, and the 
Tangjiashan flood traveled 60 kilometers with no significant attenuation. The Tanggudong landslide dam breached on June 17,1967 , discharging $6.4 \times 10^{8} \mathrm{~m}^{3}$ water over $12 \mathrm{~h}$ (Chen et al., 1992; Wang et al., 2012). Hydrological stations downstream recorded maximum flood wave heights of $50.4 \mathrm{~m}$ at the dam site, $29.6 \mathrm{~m}$ at a distance of $200 \mathrm{~km}, 20.4 \mathrm{~m}$ at $300 \mathrm{~km}$ and $16.5 \mathrm{~m}$ at $560 \mathrm{~km}$ (Chen et al., 1992) (Fig. 4B).

\subsection{Typical landslide dam outbursts}

\subsubsection{Diexi dam outbursts}

On August 25, 1933, a Ms 7.5 earthquake in Diexi, Sichuan Province, caused three landslide dams at Yinping cliff, Jiaochang and Diexi (Fig. S2) (Chai et al., 1995b; Huang, 2007) on the Min River and its tributary the Songping River. The dams impounded three lakes, Da, Xiao and Diexi, respectively (Fig. S3), that caused Min River flow to be cut off from Diexi. By September 14, Da Lake was $12.5 \mathrm{~km}$ long and $23 \mathrm{~m}$ wide and began to overflow into Xiao Lake, and on September 30, water overflowed from Xiao Lake into Diexi Lake (Chai et al., 1995b). As the elevation of Diexi dam was higher than the two upstream dams, water impounded behind it to create one vast lake with a maximum volume of $4-5 \times 10^{8} \mathrm{~m}^{3}$ (Chai et al., 1995b). A strong aftershock at 7:00 pm on October 9, 1933 triggered the collapse of seven landslide dammed lakes in the Songping valley; the flow from these lakes poured into Diexi Lake and caused it to outburst (Huang, 2007). The water depth was $60 \mathrm{~m}$ at Jiaochang, very close to the breach (Fig. S3), and was still $12 \mathrm{~m}$ high when it reached Guan County, $175 \mathrm{~km}$ downstream (Fig. 4C), where the discharge was estimated as $10200 \mathrm{~m}^{3} / \mathrm{s}$ (Yan et al., 2001). Hong (2014) estimated that 2500 people died in Maowen County and more than 8000 in Wenchuan and Guan County. 

from Xiao Lake reduced the lake level by about $20 \mathrm{~m}$ and opened up a natural spillway about 2-3 $\mathrm{km}$ in length on the Xiao dam and the remains of Diexi dam (Wang et al., 2005; Song, 2015). On June 15, 1986 the outlet of Da Lake became blocked by driftwood and part of the dam was removed in order to dredge the blockage, however, this triggered an outburst flood of 2,000-2,100

$221 \mathrm{~m} / \mathrm{s}$ (Duan and Jiang, 2004; Wang et al., 2005). The height of the outlet of Xiao Lake was 222 decreased by $12 \mathrm{~m}$ again, and the flood head was $6 \mathrm{~m}$ high at Xiao Lake dam. On June 28, 1992 combined flooding from the Min River and Songping valley entered Xiao Lake and triggered another outburst. The surface elevation of Xiao lake dropped $8.72 \mathrm{~m}$ in $33 \mathrm{~h}$, and the flood transported a $600 \mathrm{~m}^{3}$ boulder $310 \mathrm{~m}$ downstream (Wang et al., 2005; Chen, 2014). Tibetan Plateau (Huang, 2007); the hillside dropped by about $3330 \mathrm{~m}$, moved $8 \mathrm{~km}$, and the event lasted about $10 \mathrm{~min}$. (Liu et al., 2000). The dam that was created is about $2500 \mathrm{~m}$ long, $2500 \mathrm{~m}$ wide, has an average height of about $60 \mathrm{~m}$ and a volume of about $3 \times 10^{8} \mathrm{~m}^{3}$ (Yin, 2000; Liu et al., 2013) (Fig. 5). The main trigger of the landslide was water lubrication due to spring snow and ice melt, and the collapsed huge bedrock wedges was up to $5520 \mathrm{~m}$ in length (Yin, 2000). More than $1 \times 10^{8} \mathrm{~m}^{3}$ of rock slid down the steep slope, excavated the valley floor infill and eroded both sides of the valley (Liu et al., 2013). The impounded lake, termed Yigong Lake, had an average depth of $60 \mathrm{~m}$ and a volume of $2.3 \times 10^{9} \mathrm{~m}^{3}$ (Lv et al., 2002). To prevent catastrophic dam collapse, lake 
lake drained along the constructed spillway as planned, with a flow velocity of $1.0 \mathrm{~m} / \mathrm{s}$ and

238 discharge of $1.2 \mathrm{~m}^{3} / \mathrm{s}$. However, this had negligible effect on lake level and an outburst flood was

239 inevitable. At 8:00 am on June 10, the lake catastrophically outburst, with an initial flow velocity

240 of $10 \mathrm{~m} / \mathrm{s}$ and a flow rate of $2,900 \mathrm{~m}^{3} / \mathrm{s}$. After $15 \mathrm{~min}$., the water reached the downstream Tongmai

241 bridge, and by 3:00 am on June 11, the water depth at Tongmai bridge reached a maximum depth

242 of $52 \mathrm{~m}$, which exceeded the bridge deck by $32 \mathrm{~m}$, with a maximum flow rate of $12,400 \mathrm{~m}^{3} / \mathrm{s}(\mathrm{Xu}$

243 et al., 2008). The outburst flood not only destroyed Tongmai bridge, but many other bridges along

244 its route, and caused major disruption to National Highway 318, the main connecting route

245 between Chengdu and Tibet, which was not fully reconstructed until 2016 (Cheng et al., 2008a;

246 Shi et al., 2014).

\section{Moraine dams in China}

\subsection{Characteristics}

Moraine lakes are mainly formed by water impoundment in valleys dammed by end moraine

and lateral moraines abandoned by glacial retreat (Clague and Evans, 2000). In China, most of the

terminal moraine lakes that are at risk of collapse were formed by glacial retreat since the Little

Ice Age (Chen et al., 1996). Moraine-dammed glacial lakes are characterized by a steep end bounding moraines-deep lake basins (Xu and Feng, 1988). Remote sensing analysis has revealed 2515 moraine-dammed lakes $\left(>0.003 \mathrm{~km}^{2}\right)$ on the Tibetan Plateau (Fig. 6), many of which have the potential for outburst (Zhang, et al. 2015): in recent years, rising temperatures have accelerated 256 glacial melt and increased the volume of lakes (Clague and Evans 2000; Yao, et al. 2010; Wang, et 
in their stability, due to permafrost melting (Richardson and Reynolds 2000; McKillop and Clague 2007). Hence, there has been increasing interest in glacial lake outburst floods in China (e.g., Lv and Li, 1986; Xu, 1988).

As indicated above, most of the moraine lakes in China are located in Tibet; as shown in Fig. 6, Boqu and Pengqu basins (Cheng et al., 2008b). In our analysis, we found that 33 of the lakes had been affected by breaches, some of which have breached more than once (Nie et al., 2018) and identified 38 outburst events that had caused serious damage (Tab. S3). Several characteristics make moraine dams susceptible to instability, including: (1) steep slopes and lack of vegetation;

(2) very poor sorting, low compaction and poor bonding; (3) presence of melting ice cores, with shallow sediment cover (Costa and Schuster, 1988). Two further mechanisms contribute to moraine lake outburst: undermining of the dam by piping, caused by melting of buried ice, and overtopping, caused by ice landslides and avalanches into the lake (Cui et al., 2003). Our analysis suggests that the latter mechanism is dominant in China. Of the 33 moraine lake outbursts studied, 26 were attributed to dam overtopping, four to terminal moraine damage, and three to unknown reasons (Tab. S3).

\subsection{Moraine lake outburst floods}

275 Moraine lake outbursts are commonly very rapid; the flow process line is unimodal, peak discharge generally occurs within minutes to tens of minutes after dam break and the lake usually 277 is emptied within 2-3 hours (Liu, et al. 2008). Data on flood peak discharge (Q), volume released 278 (V) and breach depth (h) are available for eight of the 37 moraine lake outburst floods studied 
(Tab. 3). Regression analysis produced the fitting equation $\mathrm{Q}=0.705(\mathrm{Vh})^{0.429}, \mathrm{R}^{2}$ and $\mathrm{SE}$ are 0.51 and 60\% (Fig. 7A). Compared with the outburst floods caused by landslide dam, this fitting result is obviously worse with lower $\mathrm{R}^{2}$ and higher SE is larger. And there are two cases out of the $10 \%$ error line (Fig. 7A). Clearly, the complexity of factors that may affect moraine lake discharge means that the relationship is likely to have a level of uncertainty.

Given the location of moraine lakes in the steep upper reaches of valleys, and the large amount of dam material incorporated in the outflow, outburst floods may be transformed into debris flows (O’Connor et al., 2001; Cui et al., 2003; Liu et al., 2008), which are potentially more damaging than Newtonian water flows. In Tab. 4, we have collected data from 5 glacial lake outburst events that involved debris flows, and discuss one case below in more detail. continuous high temperature and rainfall, the lake area reached $0.523 \mathrm{~km}^{2}$ (Zhao et al, 2015). The outburst occurred instantaneously at 23:30 on July 15, after about 10 minutes, the breach cut down to the bottom. The maximum peak discharge is $1270 \mathrm{~m}^{3} / \mathrm{s}$, which lasted 0.5 hours ( $\mathrm{Li}$ and You, 1992). A large debris flow was triggered by this flood, which had a discharge of $1021 \mathrm{~m}^{3} / \mathrm{s}$, more than five times the normal river flow. The debris flow partially blocked the river, resulted in a rise in water level of more than $10 \mathrm{~m}$, and rapidly breached. The flood destroyed the roadbed for 42 $\mathrm{km}$ and interrupted traffic for 200 days (Cheng et al., 2008b).

\section{Constructed dams}


dam construction to help regulate the spatial and temporal distribution of water resources and to

301 generate power (He et al., 2008). However, due to uncertainty over factors such as geology,

302 hydrological design and construction, the risk of dam break was high, and dam failure resulted in major casualties and has been a painful lesson for the country (Wang, 2010). Zhang et al. (2014) have systematically reviewed 3520 reservoir dam failures from 1954 to 2012 dam breaches in China, but here, we could only collect 55 cases (Tab. S4). Based on data from Zhang et al. (2014), Tab. 5 shows that there were $96.3 \%$ man-made dam break as small reservoirs. Dam failures peaked in the 1970s, with more than half of the total number of dam failures during 1970s (Zhang et al., 2014). Dam failures declined considerably after the 1970s, probably due to improvements in technology and enhancement of safety awareness (Xie and Sun, 2009).

The type of material used in dam construction may also contribute to its potential for failure, with three main categories: (i) earth-rockfill, (ii) concrete and (iii) masonry (Shen, 1999). Earth and rockfill dams are constructed using local soil and stone, which is crushed (if necessary) and dumped on site (Liang, 2012), and the strength of this dam body is the weakest. Earth and rockfill dams account for $93.9 \%$ of dam failures, of which earth dams account for 93\% (Tab. 6). Overtopping is the most common cause of dam failure for earth and rockfill dams, and accounts for more than $51 \%$ of total dam failures; piping and structural instability accounted for nearly $39 \%$ of dams breaks; and management deficiency and other forms of dam break accounted for $10 \%$ (Tab. 7) (Zhou, 2010). 
has sufficient data available for quantitative analysis. Tab. 8 lists characteristics of 13 outburst floods that we used 8 earth-rock dam outburst floods in a regression analysis to quantify the relationship between peak discharge $(\mathrm{Q})$, volume released $(\mathrm{V})$ and breach depth $(\mathrm{h})$. We obtained the empirical formula $\mathrm{Q}=0.008(\mathrm{Vh})^{0.661}, \mathrm{R}^{2}$ and SE are 0.74 and $150 \%$ (Fig. 7B). Compared with the outburst floods caused by landslide dam, this fitting result is obviously worse with lower $\mathrm{R}^{2}$ and higher SE. And there are four cases out of the $10 \%$ error line (Fig. 7B). Although this relationship is based on a relatively small data set and, hence, has an unknown level of uncertainty, the formula provides a useful approach for estimating peak discharge of poorly monitored reservoir dam breaks.

The lessons of reservoir dam failure in China are very profound, and a catastrophic series of events in 1975 was particularly significant in terms of their impact on dam design and safety protocols. In 1975, the successive collapse of several reservoirs in Henan province resulted in at least 26,000 deaths and displacement of millions, were the world's deadliest reservoir collapse (Zhang et al., 2014). The event was preceded by heavy rain from super typhoon Lianna on August 4, which caused flooding in the upper reaches of Huaihe River, part of the Yellow River system, and destroyed dozens of reservoirs in the Zhumadian area of Henan province (Wang, 2013b). The event included the only two large dam failures in China, Banqiao and Shimantan reservoirs that had been constructed during the 1950s as part of a large flood control and energy generation scheme. 
August 5. Before dam breach, flow rate from upstream was $10480 \mathrm{~m}^{3} / \mathrm{s}$, but the peak discharge in

343 the spillway was only $2760 \mathrm{~m}^{3} / \mathrm{s}$, and the dam started to overtop at 11:30 pm on August 7. The

344 water level of the reservoir kept increasing, and the reservoir volume reached a maximum of about

345607.5 million $\mathrm{m}^{3}$ when the water level reached $117.94 \mathrm{~m}$ at 1:00 am on August 8, and after 30

346 minutes, the dam failed. The outburst flood had a maximum instantaneous discharge of 79,000

$347 \mathrm{~m}^{3} / \mathrm{s}$ and 7.01 million $\mathrm{m}^{3}$ of floodwater poured downstream within $6 \mathrm{~h}$ (Fig. 8) (Wang and Wang,

348 2005). The flood moved downstream at an average speed of $6 \mathrm{~m} / \mathrm{s}$, inundating the $45 \mathrm{~km}$ long

349 reach between the dam and the Beijing-Guangzhou railway with 5-9 $\mathrm{m}$ of water in a zone 12-15

350 km wide (Zhang et al., 2014).

There was a similar sequence at Shimantan reservoir on the Hong River. The dam failed after water levels rose to a depth of $111.4 \mathrm{~m}$ between August 5-8, and then 120 million $\mathrm{m}^{3}$ of water was discharged at $25-30,000 \mathrm{~m}^{3} / \mathrm{s}$ within a $5.5 \mathrm{~h}$ period. The August 1975 flood affected 11 million people, flooded 17 million areas of farmland, toppled 5.96 million houses and caused the Beijing-Guangzhou railway line to be washed-out for a distance of $102 \mathrm{~km}$ (Song, 2000) (Fig. S4). deaths from 13 reservoir dam failures, and from 2004 to 2006, there were 16 constructed dam failures and no fatalities (Zhang et al., 2014).

\section{Other outburst flood dams in China}

\subsection{Glacier dams}


a few small ice caps and no uniform large ice sheets (Shi, 2006). Therefore, there was no opportunity for development of massive glacier-dammed lakes, such as glacial lake Agassiz in North America or the subglacial East Lake in Antarctica. We only collected 6 outburst floods of this type (Tab. S5). Kargeitso and Tremucanli, on the Yarkant River, Xinjiang, are frequently subject to outburst events, with more than two per year recorded (Zhang et al., 1989; Sun et al., 2010; Wang and Ma, 2016). On August 15, 1986 an outburst flood was recorded at Kargeitso Lake, with a peak flow of $2130 \mathrm{~m}^{3} / \mathrm{s}$, and on August 5, 1987, an outburst flood occurred at the end of the Tremucanli glacier. The latter was observed by the Yarkant River Glacier Flood Scientific Expedition, who documented a peak flow of about $1500 \mathrm{~m}^{3} / \mathrm{s}$ and flood duration of $20 \mathrm{~h}$ (Wang and Ma, 2016). A snowmelt-induced outburst flood at Kargeitso Lake on August 10, 2018, was reported by CCTV news to have an initial volume of 35 million $\mathrm{m}^{3}$ and the flood discharge reached $1570 \mathrm{~m}^{3} / \mathrm{s}$ in the Yarkant River. Outburst floods also occurred for the third glacier-dammed lake, Metzbach Glacier Lake, which is located on the Kunmarek River in Kyrgyzstan. Liu et al. (1998) analyzed time-series of flood peak flow and total flood volume and identified an increasing trend of $13.69 \mathrm{~m}^{3} / \mathrm{s}$ and $0.03 \times 10^{8} \mathrm{~m}^{3}$ per year in peak discharge and total flood volume, respectively. avalanches on July 29, 1983, August 23, 1984 and June 20, 1985. Temporary lakes were formed, 381 and debris flows were generated when the avalanche dams breached. The maximum flows recorded at the mouth of the valley were 2950,5245 and $8195 \mathrm{~m}^{3} / \mathrm{s}$, respectively (Cheng et al., 2008b; Cheng et al., 2011; Liu et al., 2012). The 1983 debris flow partly blocked the Parlung Tsangpo River which the Peilong flows into, causing ponding at the confluence which raised the 
river level by $10 \mathrm{~m}$. The 1984 and 1985 glacier debris flows formed dams 14.3 and $29.3 \mathrm{~m}$ in height that impounded lakes upstream, and breaching of the dams caused powerful floods downstream (Xia, 2012).

A number of paleo-glacial-dammed lakes have been identified on the Tibetan Plaeau, the most well-studied of which is Gega, a large glacial-dammed lake at the entrance of the Tsangpo gorge, due to its significant location, and controversy over its volume and age (Zhang, 1985). Recently, detailed investigation and OSL dating by Liu et al. (2015) confirmed that Gega Lake dates in the range of uncertainty: 41-13 ka, with a dam height of $370 \mathrm{~m}$ and lake volume of $\sim 170 \mathrm{~km}^{3}$. Dam collapse was probably gradual, with a maximum peak outflow of about 500,000 $\mathrm{m}^{3} / \mathrm{s}$ (Liu, unpublished results). During the last glacial maximum, a tributary glacier of the Dong River blocked the Parlung Tsangpo and formed an 18-m thick lacustrine deposit dated to 22.5-16.1 ka (Zeng et al., 2007). Recently, Hu (2018) dated a lacustrine deposit in the middle reaches of the Yarlung Tsangpo to $32.3-13.2 \mathrm{ka}$; although the deposit was presumed to indicate a former glacier-dammed lake, no residual dam could be identified. Based on remote sensing analysis, Korup and Montgomery (2008) identified hundreds of ancient glacial dams dating to the Pleistocene in the Yarlung Tsangpo (Fig. S5), which, they suggest, indicated repeated formation of moraine and glacier dams on major rivers during the last glacial period.

\subsection{Volcanogenic dams}

Outburst floods triggered by volcanic activity, especially crater lake outbursts, have attracted widespread attention worldwide (Manville, 2010). We collected 10 volcanic lakes in China (Tab. 9). However, most volcanoes are inactive, except for Tianchi on Changbai Mountain in northeast 
China, from which several caldera lake outburst floods have been reported (Fig. S6; Liu et al., 1997). Wei et al. $(2003,2004)$ suggested that a volcanic eruption at Tianchi c. 1 ka BP triggered a $0.3 \mathrm{~km}^{3}$ landslide into Tianchi lake from the north of Baiyun Peak, which caused the lake to rise by $33 \mathrm{~m}$ and an outburst with an estimated peak discharge of $20000 \mathrm{~m}^{3} / \mathrm{s}$ (Wei et al., 2003, 2004). At present, the Tianchi caldera lake is much larger, with a volume of about 2.04 billion $\mathrm{m}^{3}$. An outburst from this lake could produce a flood with velocities exceeding of $25 \mathrm{~m}^{3} / \mathrm{s}$ and depths up to $20 \mathrm{~m}$ (Wang, 2013a; Li, 2015). contain potentially significant volumes of water. For example, Jingpo volcanic lava dammed lake is $45 \mathrm{~km}$ long, $90.3 \mathrm{~km}^{2}$ in area and contains 1.625 billion $\mathrm{m}^{3}$ of water (Fan et al., 2003). Although research, such as Huguangyan maar lake (Liu et al., 2017), this approach has not yet been applied to paleoflood reconstruction of outburst events.

\subsection{Rock-bound dams}

Overflow from rock-bound tectonic basins has been linked with significant flooding geologically (Garcia-Castellanos and O'Connor, 2018). In recent years, due to the increase of precipitation, many lakes area have increased in Hohxil region (Yao et al., 2012). The increase in the volume of lakes caused some to overflow and outburst. There have been cascade outbursts of two lakes in 2011 (Tab. S6; Fig. S7). The Zhuonai Lake first overflowed on August 22, 2011, and it is estimated that the outburst flood was formed on September 14 to 21(Yao et al., 2012). The 

from Kusai Lake entered the downstream Salt Lake, which resulting in the area of Salt Lake rapidly increase, and together with the expected increasing precipitation in future, the Salt Lake may also happen overtopping (Liu et al., in press).

431 It has been suggested that basins in the upper Yellow River may have integrated through basin spillover since c. 1.8 Ma (Craddock et al., 2010). The upper reaches of other large rivers originating on the Tibetan Plateau also flow through many lake basins (Ming, 2007), so floods from basin spillovers may have been more significant in China than previously recognized. beaver dams, beach-barrier spits, and sand dunes blocking rivers. However, O'Connor et al. (2013) suggest that these sorts of outburst floods are of relatively modest discharge (up to $1 \times 10^{4} \mathrm{~m}^{3} / \mathrm{s}$ ), so are not discussed further here.

\section{Future study of outburst flood in China}

\subsection{Reconstruction of outburst floods using sedimentary evidence}

There is an increasing worldwide body of research on the sedimentology and depositional

443 record of modern and outburst events (Carling, 2013). In China, outburst flood deposits have

444 begun to be recognized and analyzed (e.g., Cui et al. 2005; Chen and Cui, 2015), but failed to reconstruct paleoflood hydraulics. We have identified a series of sedimentary facies associations due to high magnitude outburst flooding in the Quaternary in the Yarlung Tsangpo River (Fig. 9A- 
F), the Salween River (Fig. 9G), Jinsha River and Dadu River. A goal for future work is to establish the chronology, sedimentology and paleo-hydraulics of these extreme flood events, especially in the Tibetan Plateau region.

\subsection{Effect of outburst floods on Tibetan Plateau incision}

Although the margin of the Tibetan Plateau is sculpted by deep gorges, and featured by steep river channel (Clark et al., 2006), most rivers are not in direct contact with bedrock due to sediment draping the channel floor. The process of bedload transport maybe the rate-limiting factor for river incision (Molnar, 2001). The existence of a discharge threshold for basal shear stress to transport bedload, and the tight scaling of bedload (clast size and quantity) to flow depth and velocity, enhances the hydraulic effectiveness of individual rare floods for river channel incision. Therefore, the role of cataclysmic floods in gorge incision may be critical (Lang et al., 2013). The relative significance of long-term slow erosion by low magnitude/high frequency flows compared to the rarer, more episodic, and intense effects of high magnitude discharges, should be a key area for future study.

\subsection{Effect of outburst floods on civilization of China}

Bromiley (1988) suggested that most flood myths originated from real events, and there were geological evidences for many flood legends that suggests some resulted from outburst floods (Baker, 2009). For example, the Noah's Ark flood has been linked to the filling of the Black Sea by seawater due to sea level rise at 8400 BP (Ryan and Pitman, 2000). The Yu control of a great flood is also fundamental to Chinese early culture (Chen, 2005). Recently, Wu et al. (2016) suggested that the Yu Era flood might have its basis in an outburst flood that resulted from a 
landslide dam at Jishi gorge in the upper reaches of the Yellow River. Although this hypothesis has been widely debated (Han, 2017; Huang et al., 2017), the distribution of many ancient human sites in China overlaps with that of barrier dams/outburst floods (Fig. S8), indicating fertile fields of future research on the impact of outburst floods on ancient human development.

\section{Conclusions}

We have shown that outburst floods have been frequent occurrences in China, including those generated by failure of landslide, moraine and artificial dams, but detailed information on such events is relatively scarce. Of 287 landslide dam events we collected, details such as peak discharge were recorded in only 20 cases; the maximum outburst flood discharge was $1.24 \times 10^{5}$ $\mathrm{m}^{3} / \mathrm{s}$ and the minimum only $1,200 \mathrm{~m}^{3} / \mathrm{s}$. In 33 cases of moraine-dammed lakes, all the outburst floods transformed into debris flows, which enhanced their impacts. From 1954 to 2012, there were 3520 reservoir dam failures. Although there are very few glacier-dammed lakes and basin spillovers in China today, evidence indicates their wide distribution on the Tibetan Plateau in the Pleistocene, and their potential significance for megaflood generation. Volcanic-related floods, although not detected in China to date, are highly likely to have occurred. Several recently-discovered giant gravel bars on the southeastern Tibetan Plateau may record megafloods.

\section{Acknowledgements}

The authors would like to thank reviewers (Jim E. O'Connor and anonymity) and Victor R. Baker (editor) for constructive comments and suggestions. This work was Supported by the 
20030301), the National Natural Science Foundation of China (grant number 41771023, 41661144028 and 41771023), and the Open Research Fund Program of the State Key Laboratory of Hydroscience and Engineering (sklhse-2018-B-01). The authors thank Yiwei Huang, Ting Cheng and Kunting Chen for help collecting information. Most of the data in this article are derived from published materials.

\section{References}

Baker, V. R., 2009. Overview of megaflooding: Earth and Mars. In: Burr, D.M., Carling, P.A. and Baker, V.R.(Ed.), Megaflooding on Earth and Mars. Cambridge University Press, Cambridge, pp. 1-12.

Baker, V. R., 2013. Global late quaternary fluvial paleohydrology: with special emphasis on paleofloods and megafloods. In: Shroder, J., Wohl, E.E. (Ed.), Treatise on Geomorphology. Fluvial Geomorphology vol. 9. Academic Press, San Diego, pp. 511-527.

Bromiley, G., 1988. Deluge. In: Bible, W. and Society, T.(Ed.), Insight on the Scriptures. International Bible Students Association, Brooklyn, pp. 609-612.

Burke, M. J., Woodward, J., and Russell, A. J., 2010. Sedimentary architecture of large-scale, jökulhlaup-generated, ice-block obstacle marks: Examples from Skeiðarársandur, SE Iceland. Sediment. Geol. 227, 1-10.

Carling, P. A., 2013. Freshwater megaflood sedimentation: what can we learn about generic processes? Earth-Sci. Rev. 125, 87-113.

Cenderelli, D. A., 2000. Floods from natural and artificial dam failures. In: Wohl, E.E. (Ed.), Inland Flood Hazards: Human, Riparian, and Aquatic Communities. Cambridge University Press, Cambridge, pp. 73-103.

Chai, H. J., Liu, H. C. and Zhang, Z. Y., 1995a. The catalog of Chinese landslide dam events. J. Geol. Hazard. Environ. Preserv. (4), 1-9 (in Chinese with English abstract).

Chai, H.J., Liu, H.C. and Zhang, Z.Y., 1995b. Landslide dams induced by Diexi earthquake in 1933 and its environmental effect. J. Geol. Hazard. Environ. Preserv. 6(1), 7-17 (in Chinese with English abstract).

Chen, C.J., Liu, M. and Zhang, Z., 1996. Outburst conditions of moraine-dammed lakes and their flood estimation in the headwaters of the Nianchu River, Tibet. Journal of Glaciolgy and Geocryology 18(4), 347-352 (in Chinese with English abstract).

Chen, J. and Cui, Z.J., 2015. Discovery of outburst deposits induced by the Xuelongnang Paleolandslide-Dammed Lake in the upper Jinsha River,China and its environmental and hazard significance. Acta Sediment. Sin. 33(2), 275-284 (in Chinese with English abstract).

Chen, J.X., 2005. On the flood story circle in China -on the structural analysis of 568 different texts. Ph. D Dissertation. Huazhong Normal University, Wuhan, Hubei, China, 138 pp. (in Chinese with English abstract). 
Chen, N., 2014. The stability analysis of Xiao Lake barrier dam, Diexi. China Water Transport 14(12), 180-181 (in Chinese with English abstract).

Chen, Y.J., Zhou, F., Feng, Y. and Xia, Y.C., 1992. Breach of a naturally embanked dam on Yalong River. Can. J. Civil Eng. 19(5), 811-818 (in Chinese with English abstract).

Chen, Y.T., 2008. Study on disaster China of debris flow caused by glacial lake outburst in the Himalayas, M.Eng. dissertation, Jilin University, China, 91 pp. (in Chinese with English abstract).

Cheng, Z.L., Cui, P., Li, Y., You, Y. and Chen, X.Q., 2008a. Major disasters and countrtmeasures of dammed lakes from landslides and debris flows. J. Mt. Sci-Engl. 26(6), 733-738 (in Chinese with English abstract).

Cheng, Z.L., Hong, Y. and LI, X.Y., 2011. The warning technology of debris flow caused by glacier-lake outburst in Qinghai-Tibet Plateau. J. Mt. Sci-Engl. 29(3), 369-377 (in Chinese with English abstract).

Cheng, Z.L., Zhu, P.Y., Dang, C. and Liu, J.J., 2008b. Hazards of debris flow due to glacier-lake outburst in southeastern Tibet. J. Glaci. Geocry. 30(6), 954-959 (in Chinese with English abstract).

Clague, J.J. and Evans, S.G., 2000. A review of catastrophic drainage of moraine-dammed lakes in British Columbia. Quat. Sci. Rev. 19, 1763-1783.

Clark, M.K., Royden, L.H., Whipple, K.X., Burchfiel, B.C., Zhang, X. and Tang, W., 2006. Use of a regional, relict landscape to measure vertical deformation of the eastern Tibetan Plateau. J. Geophys. Res., 111, F03002, doi: 10.1029/2005JF000294.

Costa, J.E., 1985. Floods from dam failures. Open-File Rep. No. 85-560, U.S. Geological Survey, Denver.

Costa, J.E. and Schuster, R.L., 1988. The formation and failure of natural dams. Geol. Soc. Am. Bull. 100, 1054-1068.

Craddock, W.H., Kirby, E., Harkins, N.W., Zhang, H., Shi, X., and Liu, J., 2010, Rapid fluvial incision along the Yellow River during headward basin integration: Nat. Geosci. 3(3), 209-213.

Cui, P., Han, Y.S., Chao, D. and Chen, X.Q., 2011. Formation and treatment of landslide dams rmplaced during the 2008 Wenchuan rarthquake, Sichuan, China, 133. Springer, Berlin Heidelberg, pp. 295-321.

Cui, P., Han, Y.S. and Chen, X.Q., 2009. Distribution and risk analysis of dammed lakes reduced by Wenchuan earthquake. J. Sichuan University(Eng. Sci. Edition) 41(3), 35-42 (in Chinese with English abstract).

Cui, P., Ma, D.T. and Chen, N.S., 2003. The initiation, motion and mitigation of debris flow caused by glacier lake outburst. Quat. Sci. 23(6), 621-628 (in Chinese with English abstract).

Cui, Z.J., Zhang, M., Cui, P., Chen, J., Wei, M.J., Chen, Y.X. and Li, C.C., 2005. Discussion on characteristics of sedimentary facies of dammed-lakes outburst deposits. Mt. Res. 33(2), 129 -141(in Chinese with English abstract).

Dai, F.C., Lee, C.F., Deng, J.H. and Tham, L.G., 2005. The 1786 earthquake-triggered landslide dam and subsequent dam-break flood on the Dadu River, southwestern China. Geomorphology 65, 205-221.

Deng, Q.D., Zhang, P.Z., Ran, Y.K., Yang, X.P., Min, W. and Chen, L.C., 2003. Active tectonics and earthquake activities in China. Earth Sci. Front. 10, 66-73 (in Chinese with English 
abstract).

Du, Y., 1987. Three commentaries on the spring and autumn annals. Shanghai Classics Publisher, Shanghai, 602 pp. (in Chinese).

Duan, Q.Z. and Jiang, M.Y., 2004. Stability analysis of the Da Lake dam in Diexi, Min River. Sichuan Water Power 23(1), 93-96 (in Chinese with English abstract).

Fan, Q.C., Sun, Q., Li, N., Yin, J.H., Chen, H.Z., Gao, F. and Zhang, X.J., 2003. The section of airfall clastic rock of holocene volcano in Jingpohu region and its eruptive history. Seismol. Geol. 25(b12), 3-11 (in Chinese with English abstract).

Froehlich, D. C., 2016. Predicting peak discharge from gradually breached embankment dam. J. Hydrol. Eng. 21: 04016041, doi: 10.1061/(ASCE)HE.1943-5584.0001424.

Garcia-Castellanos, D. and O'Connor, J.E., 2018. Outburst floods provide erodability estimates consistent with long-term landscape evolution. Sci. Rep. 8, doi:10.1038/s41598-018-28981-y.

Han, J.C., 2017. Comment on "Outburst flood at 1920 BCE supports historicity of China's Great Flood and the Xia dynasty". Science, 355, 1382-1382.

He, X.Y., Wang, Z.Y. and Huang, J.C., 2008. Analysis on the spatial distribution of dam-failure in China. J. Catastroph. 23(2), 1-4 (in Chinese with English abstract).

Hong, S.Z., 2014. Textual research about death toll in Diexi earthquake. Earthq. Res. Sichuan (3), 6-10 (in Chinese with English abstract).

Hu, H.P., Feng, J.L. and Chen, F., 2018. Sedimentary records of a palaeo-lake in the middle Yarlung Tsangpo: Implications for terrace genesis and outburst flooding. Quat. Sci. Rev. 192, 135-148.

Huang, C.C., Zhou, Y., Zhang, Y., Guo, Y., Pang, J., Zhou, Q., Liu, T. and Zha, X., 2017. Comment on "Outburst flood at 1920 BCE supports historicity of China's Great Flood and the Xia dynasty”. Science 355, 1382-1382.

Huang, R.Q., 2007. Large-scale landslides and their sliding mechanisms in China since the 20th century. Chin. J. Mech. Eng-En. 26(3), 433-454 (in Chinese with English abstract).

Huang, R.Q. and Xu, Q., 2008. Catastrophic landslides in China. Science Press, Beijing, China, 553 pp. (in Chinese)

Jia, W.H., 2013. The textual research of Duyu. Soc. Sci. Res. (3), 182-187 (in Chinese).

Jiang, Z.X., 2006. The 1786 Kangding-Ludin-Moxi earthquake, flood and relief-220th anniversary. Earthq. Res. Sichuan (3), 4-9 (in Chinese with English abstract).

Korup, O. and Montgomery, D.R., 2008. Tibetan Plateau river incision inhibited by glacial stabilization of the Tsangpo Gorge. Nature 455, 786-789.

Lang, K.A., Huntington, K.W. and Montgomery, D.R., 2013. Erosion of the Tsangpo Gorge by megafloods, Eastern Himalaya. Geology 41, 1003-1006.

Li, D.J. and You Y. 1992 Bursting of the MIdui moraine lake in Bomi, Xizang, Mountain Res.10(4), 219-224 (in Chinese with English abstract).

Li, M.Y., 2015. Numerical simulation of Changbaishan Tianchi outburst flood by digital elevation model, M.S. dissertation, Ocean University of China, China, 102 pp. (in Chinese with English abstract).

Liang, H.A., 2012. Seismic damage prediction and emergency of earth-rock dam, Ph.D. dissertation, Institute of Engineering Mechanics, China Earthquak, China, 200 pp. (in Chinese with English abstract). 
Liu, J.F., Cheng, Z.L. and Chen, X.Q., 2012. The hazard assessment of glacier-lake outburst in Palongzangbu River from Ranwu to Peilong. J. Mt. Sci. 30(3), 369-377 (in Chinese with English abstract).

Liu, J.J., Cheng, Z.L., Li, Y. and Su, P.C., 2008. Characteristics of glacier-lake breaks in Tibet. J. Catastroph. 23(1), 55-60 (in Chinese with English abstract).

Liu, J.Q., 1999. China's volcano. Science Press, Beijing, China, 215 pp. (in Chinese).

Liu, N., Cheng, Z.L., Cui, P. and Chen, N.S., 2013. Dammed lake and risk management. China Science Publishing, Beijing, China, 388 pp. (in Chinese).

Liu, N., Jiang, N.M., Yang, Q.G., Xue, G.F. and Wan, H.B., 2000. On emergency treatment scheme for Yigong massive landslide and river blockage disaster in Tibet. Yangtze River 31(9), 10-12 (in Chinese with English abstract).

Liu, R.X., Qiu, S.H., Cai, L.Z., Wei, H.Q., Yang, Q.F., Xian, Z.Q., Bao, G.C. and Zhong, J., 1997. The date of the last major eruption of tianchi volcano in changbai mountain and its significance. Sci. China (Series D) 27(5), 437-441 (in Chinese).

Liu, S.Y., Cheng, G.D. and Liu, J.S., 1998. Jokulhlaup characteristics of the lake Mertzbakher in the Tianshan Mountains and Its relation to climate change. J. Glaci. Geocry. 14(2), 112-22 (in Chinese with English abstract).

Liu, W., 2006. Preliminary study on debris flow induced by glacier lake outburst in Tibet. Hydrogeol. Eng. Geol. 33(3), 88-92 (in Chinese with English abstract).

Liu, W., Lai, Z., Hu, K., Ge, Y., Cui, P., Zhang, X. and Liu, F., 2015. Age and extent of a giant glacial-dammed lake at Yarlung Tsangpo Gorge in the Tibetan Plateau. Geomorphology 246, 370-376.

Liu, W., Xie, C., Wang W., Zhang Y., Yang G., Liu G., in press. Analysis on expansion trend and outburst risk of the Yanhu Lake in HohXil region, Qinghai. J. Glaci. Geocry. 41, doi: 10.7522/j.issn.1000-0240.2019.0307(in Chinese with English abstract).

Liu, X.Y., Zhan, T., Liu, L., Zhou, X., Qiao, Y.S., Luyao, T.U., Yongfa, M.A., Jiang, X., Zhang, J. and Lou, B.J., 2017. Grain-size of organic debris in sediments from Wudalianchi crater lake in Heilongjiang province record the evolution of summer monsoon precipitation at millennial-to centennial-scale in the early holocene. Acta Geol. Sin. 91(12), 2854-2866 (in Chinese with English abstract).

Lu, Z.Y., 1988. Basic types, characteristics and countermeasures of landslides blocking the river. China Railway Publishing House, Beijing, China, pp. 108-118 (in Chinese).

Lv, J.T., Wang, Z.H. and Zhou, C.H., 2002. A tentative discussion on the monitoring of the Yigong landslide-blocked lake with satellite remote sensing technique. Acta Geosci. Sin. 23(4), 363-368 (in Chinese with English abstract).

Lv, R.R. and Li, D.J., 1986. Debris flow induced by ice lake burst in the Tangbulang gully, Gongbujiangda, Tibet. J. Glaci. Geocry. 8(1), 61-71 (in Chinese with English abstract).

Manville, V., Woodward, J.C., Brewer, P.A., Macklin, M.G. and Tooth, S., 2010. An overview of break-out floods from intracaldera lakes. Global Planet. Change 70, 14-23.

Mckillop, R.J. and Clague, J.J., 2007. Statistical, remote sensing-based approach for estimating the probability of catastrophic drainage from moraine-dammed lakes in southwestern British Columbia. Global Planet. Change 56, 153-171.

Ming, Q.Z., 2007. The landform development and environmental effects of three parallel rivers. China Science Publishing, Beijing, China, 200 pp. (in Chinese). 
Molnar, P., 2001. Climate change, flooding in arid environments, and erosion rates. Geology 29, 1071-1074.

Nie, Y., Liu, Q., Wang, J., Zhang, Y., Sheng, Y.W. and Liu, S.Y., 2018. An inventory of historical glacial lake outburst floods in the Himalayas based on remote sensing observations and geomorphological analysis. Geomorphology 308, 91-106.

O'Connor, J.E., Clague, J.J., Walder, J.S., Manville, V. and Beebee, R.A., 2013. 9.25 Outburst Floods. In: F.S. Editor-in-Chief: John (Ed.), Treatise on Geomorphology. Academic Press, San Diego, pp. 475-510.

O'Connor, J.E., Hardison, J.H., Costa, J.E., 2001. Debris flows from failures of Neoglacial-age moraines in the Three Sisters and Mount Jefferson wilderness areas, Oregon. US Geol. Surv. Prof. Pap. 1606.

O'Connor, J.E. and Beebee, R.A., 2009. Floods from natural rock-material dams. In: Burr, D. M., Carling, P.A. and Baker, V.R. (Ed.), Megaflooding on Earth and Mars. Cambridge University Press, Cambridge, pp. 128-171.

Peng, M., and Zhang, L. M., 2012, Breaching parameters of landslide dams. Landslides 9, 13-31.

Richardson, S.D. and Reynolds, J.M., 2000. An overview of glacial hazards in the Himalayas. Quat. Int. 65, 31-47.

Ryan, W. and Pitman, W., 2000. Noah's flood: the new scientific discoveries about the event that changed history. Simon \& Schuster, New York, 307 pp.

Shang, Y., Yang, Z., Li, L., Liu, D.A., Liao, Q. and Wang, Y., 2003. A super-large landslide in Tibet in 2000: background, occurrence, disaster, and origin. Geomorphology 54, 225-243.

Shen, C.G., 1999. Present status and development of Chinese large dam construction. China Power 32(12), 12-19 (in Chinese).

Shi, Y.F., 2006. The quaternary glaciations and environment variations in China. Hebei Science and Technology Press, Shijiazhuang, China, 618 pp. (in Chinese).

Shi, Z.M., Ma, X.L., Peng, M. and Zhang, L.M., 2014. Statistical analysis and efficient dam burst modelling of landslide dams based on a large-scale database. Chin. J. Mech. Eng. 33, 1780-1790 (in Chinese with English abstract).

Song, E.L., 2000. Analysis on the causes of several dam accidents in China. Dam and Safety 14(2), 41-44 (in Chinese).

Song, L., 2015. Landslide damming in western Sichuan Province, China, with special reference to the 1786 Dadu River and 1933 Diexi events, M.S. dissertation, University of Waterloo, Waterloo.

Sun, G.L., Chen, Y.N., Li, W.H., Wang, Y.Z. and Yang, Y.H., 2010. The response of glacial lake outburst floods to climate change in the Yarkant River, Xinjiang. J. Glaci. Geocry. 32(3), 580-586 (in Chinese with English abstract).

Walder, J.S. and O'Connor, J.E., 1997. Methods for predicting peak discharge of floods caused by failure of natural and constructed earthen dams. Water Resour. Res. 33(10), 2337-2348.

Wang, J. and Ma, Y.J., 2016. Analysis of dam outburst flood in Yarkant River, Xinjiang. China Water Transp. 16(6), 212-214 (in Chinese).

Wang, K. and Shen, Z.K., 2011. Location and facal mechanism of the 1933 Diexi earthquake and its associated regional tectonics. Acta Seism. Sin. 33(5), 557-567 (in Chinese with English abstract). 
Wang, K.W., Deng, C.J. and Zhang, F., 2012. Formation process of Tanggudong landslide and Yuri accumulation body in Yalong River valley in southwest China. J. Eng. Geol. 20(6), 955-970 (in Chinese with English abstract).

Wang, T.H., 2010. Study on the risk analysis of dam safety emergency management region and the methods of losses assessment, M.Eng. dissertation, Changjiang River Scientific Research Institute, China, 96 pp. (in Chinese with English abstract).

Wang, X., Ding, Y., Liu, S., Jiang, L., Wu, K., Jiang, Z. and Guo, W., 2013. Changes of glacial lakes and implications in Tian Shan, central Asia, based on remote sensing data from 1990 to 2010. Environ. Res. Lett. 8, 575-591.

Wang, X.D., 2013a. Prediction research on crater lake break-out lahar hazard of Changbai Mountain, Ph.D. dissertation, Jilin University, China, 168 pp. (in Chinese with English abstract).

Wang, Y.R., 2013b. The "75•8" catastrophic flood disaster in Henan province. Water Resour. South-to-North. Water Diver (21), 35-39 (in Chinese).

Wang, Y.R. and Wang, Z.Y., 2005. The "75•8" catastrophic flood disaster in Henan province. Yellow River Water Conservancy Press, China, 305 pp. (in Chinese).

Wang, Y.X., 1995. Mechanics, dynamics and hydrology of the flood resulting from the landslide dam break on Kuitun River, Xinjiang. Chin. J. Geologi. Hazard Control 6(1), 15-23 (in Chinese with English abstract).

Wei, H., Sparks, R.S.J., Liu, R., Fan, Q., Wang, Y., Hong, H., Zhang, H., Chen, H., Jiang, C. and Dong, J., 2003. Three active volcanoes in China and their hazards. J. Asian Earth Sci. 21, 515-526.

Wei, H.Q., Hong, H.J., Sparks, R.S.J., Walder, J.S. and Han, B., 2004. Potential hazards of eruptions around the Tianchi Caldera Lake, China. Acta Geol. Sin. 78, 790-794.

Westoby, M.J., Glasser, N.F., Brasington, J., Hambrey, M.J., Quincey, D.J. and Reynolds, J.M., 2014. Modelling outburst floods from moraine-dammed glacial lakes. Earth-Sci. Rev. 134, 137-159.

Wu, Q., Zhao, Z., Liu, L., Granger, D.E., Wang, H., Cohen, D.J., Wu, X., Ye, M., Baryosef, O. and Lu, B., 2016. Outburst flood at 1920 BCE supports historicity of China's Great Flood and the Xia dynasty. Science 353, 579-582.

Xia, Z.Y., 2012. The research of distribution and formation for debris flow due to break of glacier lake in the Ranwu-Peilong section of The Sichuan-Tibet, M.S. dissertation, Chongqing Jiaotong University, China, 80 pp. (in Chinese with English abstract).

Xie, J.B. and Sun, D.Y., 2009. Statistics of dam failures in China and analysis on failure causations. Water Resour. Hydropower Eng. 40(12), 124-128 (in Chinese).

Xu, D.M., 1988. Characteristics of debris flow caused by outburst of glacial lake in Boqu river, Xizang, China, 1981. Geojournal 17, 569-580.

Xu, D.M. and Feng, Q.M., 1988. Studies on catastrophes of glacial debrisflow and glacial Lake outburst flood in China. J. Glaci. Geocry. 10(3), 284-289 (in Chinese).

Xu, D.M., Liu, C.H. and Feng, Q.H., 1989. Dangerous glacial lake and outburst features in Xizang Himalayas. Acta Geographica Sin. 44(3), 343-352 (in Chinese with English abstract).

$\mathrm{Xu}$, Q. and Li, W.L., 2010. Distribution of large-scale landslides induced by the Wenchuan earthquake. J. Eng. Geol. 18(6), 818-826 (in Chinese with English abstract).

Xu, Q., Wang, S.T., Chai, H.J. and Zhang, Z.Y., 2008. Yigong rock avalanche-flow landslide event, Tibet, China. In: Chen, Z.Y., Zhang, J.M., Ho, K., Wu, F.Q., Li Z.K.(Eds.), Landslides and 
Engineered Slopes. From the Past to the Future. CRC Press 1850 pp. 1675-1680.

Yan, E.C., Zheng, W.M., Tang, H.M. and Liu, H.C., 2001. Theoretics analyse on outburst flood from landslide and its evolution process. Hydrogeo. Eng. Geol. 28(6), $15-17$ (in Chinese with English abstract).

Yang, X., 1993. The book of Shu king. Shanghai Classics Press, Shanghai, China (in Chinese).

Yao, T.D., Li, Z.G., Wei, Y., Guo, X.J., Zhu, L.P., Kang, S.C., Wu, Y.H. and Yu, W.S., 2010. Glacial distribution and mass balance in the Yarlung Zangbo River and its influence on lakes. Sci. Bull. 55, 2072-2078.

Yao, X. J., Liu, S. Y., Sun, M. P., Guo, W., and Zhang, X., 2012. Changes of Kusai Lake in Hoh xil region and causes of its water overflowing. Acta Geographica Sinica, 67(5), 689-698 (in Chinese with English abstract).

Yao, X.J., Liu, S.Y., Sun, M.P. and Zhang, X.J., 2014. Study on the glacial lake outburst flood events in Tibet since the 20th century. J. Natural Resources, 29(8), 1377-1390 (in Chinese with English abstract).

Ye, H., 1977. Discussion on the causes of dam failure at the whelk reservoir in Lanxi county. Zhejiang Water Conserv. Tech. 3-6 (in Chinese).

Yin, Y.P., 2000. A survey of giant landslide at the Yigong, Tibet. Chin. J. Geologi. Hazard Control 11(2), 100 (in Chinese).

Zeng, Q.1., Yang, Z.F., Yuan, G.X., Shang, Y.J., Zhang, L.Q. and Zhao, X.T., 2007. Songzong lake:an ice-dammed lake of last glacial maximum in Purlung Tsangpo River,southeast Tibet. Quat. Sci. 27(1), 85-92 (in Chinese with English abstract).

Zhang, G.Q., Yao, T.D., Xie, H.J., Wang, W.C. and Yang, W., 2015. An inventory of glacial lakes in the Third Pole region and their changes in response to global warming. Global Planet. Change 131, 148-157.

Zhang, J.Y., Yang, Z.H. and Jiang, J.P., 2014. A study on reservoir dam defects and breaches in China. Science Press, Beijing, China, 290 pp. (in Chinese).

Zhang, W.J., 1985. Some features of the surge glacier in the Mt. Namjagbarwa. Mt. Res. 3(4), 234-238 (in Chinese with English abstract).

Zhang, X.S., Li, N.J., You, X.Y. and Wang, W.X., 1989. Study on sudden flood in glacier lake of Yarkant River in Xinjiang. Chin. Sci. Chem: Chin. Sci. 19(11), 1197-1204 (in Chinese).

Zhao, W.Y., Chen, X.Q., Liu, J.K., Su, F.H., 2015. Outburst-regeneration characteristic and mechanism of glacier lake. Mountain Res. 33(6), 703-712 (in Chinese with English abstract).

Zheng, S.R., 2012. Discussion of safety issues of reservoir dam in China. Yangtze River 43(21), 1-5 (in Chinese with English abstract).

Zhou, Y.F., 2010. Numerical simulation study on dam-break flow of Da Nanchuan, M.Eng. dissertation, Changsha University of Science and Technology, China, 56 pp. (in Chinese with English abstract). 


\section{Figure Captions}

784

785

786

787

788

789

790

791

792

793

794

795

796

797

798

799

800

801

802

803

804

805

806

807

808

809

810

811

812

813

814

815

816

817

818

819

Figure 1. Distribution of natural and artificial dams in China. See main text for dams sources. Faults come from Deng (2003).

Figure 2. Schematic diagrams of typical types dam and possible outburst mechanism. (A) Landslide dam, (B) moraine dam, (C) artificial dam. Overtopping, surge due to landslide and ice collapse, seepage, earthquake and stability failure are the main causes of the outburst flood of damming lake. (C) is adapted from Westoby et al. (2014).

Figure 3. Relationship between landslide dam outburst peak discharge $(\mathrm{Q})$ and lake parameters. (A) $\mathrm{Q}$ vs Breach depth (h), $\mathrm{Q}=33.951 \mathrm{~h}^{1.670}$; (B) $\mathrm{Q}$ vs volume of water drained from the lake $(\mathrm{V})$, $\mathrm{Q}=0.024 \mathrm{~V}^{0.701}$; (C) $\mathrm{Q}$ vs the product of $\mathrm{V}$ and $\mathrm{h}, \mathrm{Q}=0.083(\mathrm{Vh})^{0.535}$. Numbers of observations $(\mathrm{N})$, coefficient of determinations $\left(\mathrm{R}^{2}\right)$, standard errors (SE) and $10 \%$ error lines are also shown.

Figure 4. Landslide dam outburst flood attenuation. (A) Peak discharge attenuation for three events, see Tab. 1 for details; (B) Attenuation of peak depth for Tanggudong flood. (C) Attenuation of peak depth downstream of the Diexi landslide dam.

Figure 5. Yigong landslide dammed lake in 2000 (Landsat 8 image taken on May 4, 2000).

Figure 6. Location of moraine-dammed lakes in China. Information on modern moraine lakes is from Zhang et al. (2015). Outburst moraine lakes are from table S3.

Figure 7. Regression relationship for moraine dam outburst floods, $Q=0.953(\mathrm{Vh})^{0.414}$ (A), and constructed dam outburst floods, $\mathrm{Q}=0.023(\mathrm{Vh})^{0.484}(\mathrm{~B})$.

Figure 8. Flood hydrograph for the catastrophic Banqiao reservoir outburst flood in 1975 (C). Where $\mathrm{Q}$ is peak discharge $(\mathrm{Q}), \mathrm{h}$ is lake level, and $\mathrm{V}$ is the volume of water drained from the lake. Numbers of samples $(\mathrm{N})$ and correlation coefficients $(\mathrm{R})$ are also shown.

Figure 9. Photos of sedimentary sequences formed during cataclysmic flood in Yarlung Tsangpo River(A, B, C, D, E) and Nu Jiang River(G). (A) Massively deposited pebble to gravel, scattered boulders settled suspension are observed. (B) Weakly horizontally stratified coarse sand to pebble, outcropped at the crest of low-relief hill, representing the suspension fall-out due to flow depth and velocity loss as the flood inundated the hill during the waxing stage. (C) Satellite image from google earth show the location of fig. A, B and D Terrace made up of massively deposited pebble to boulders, deposited laterally against a thin bedrock ridge at the mouth of bedrock gorge, which we interpret as deposition due to rapid settling down of suspension caused by flow expansion. (E) Top view of outcropped sections in fig.D. (F) Terrace of downstream dipping and downstream convergent foresets of sand to gravel in which rounded and angular gravel both exist, usually interpreted as the bedload deposition in the middle of channel during cataclysmic floods (Burke et al., 2010). Channel bar could also deposit similar sedimentary sequence, but not in this scale of 24 $\mathrm{m}$ relative height. (G) Massively deposited pebble to boulder, outsized boulders are dispersedly distributed. Detailed location information for these photos is shown in Tab. S7. 
$80^{\circ} \mathrm{E}$

$100^{\circ} \mathrm{E}$

$120^{\circ} \mathrm{E}$

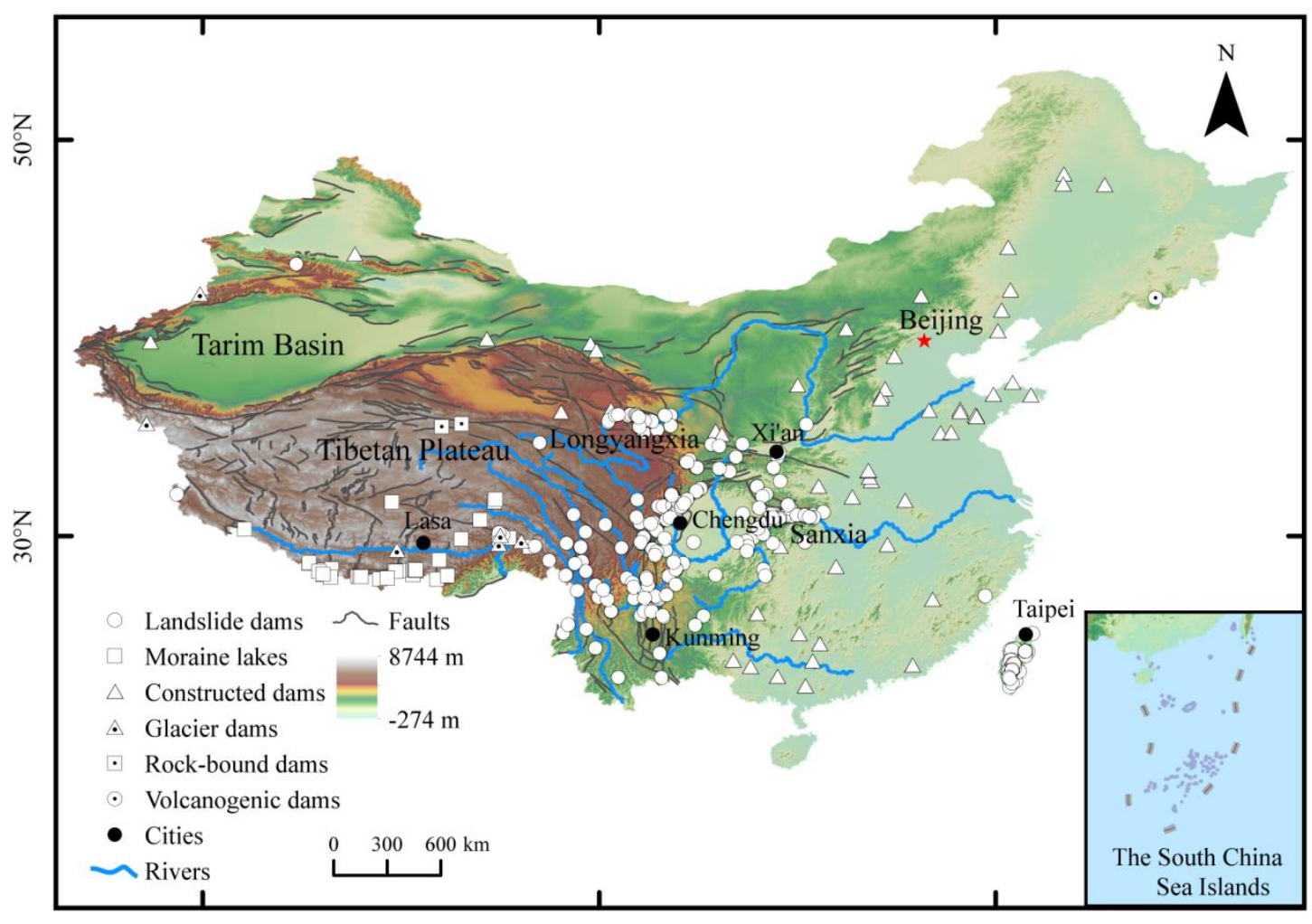

820

\section{$821 \quad$ Figure 1.}

822
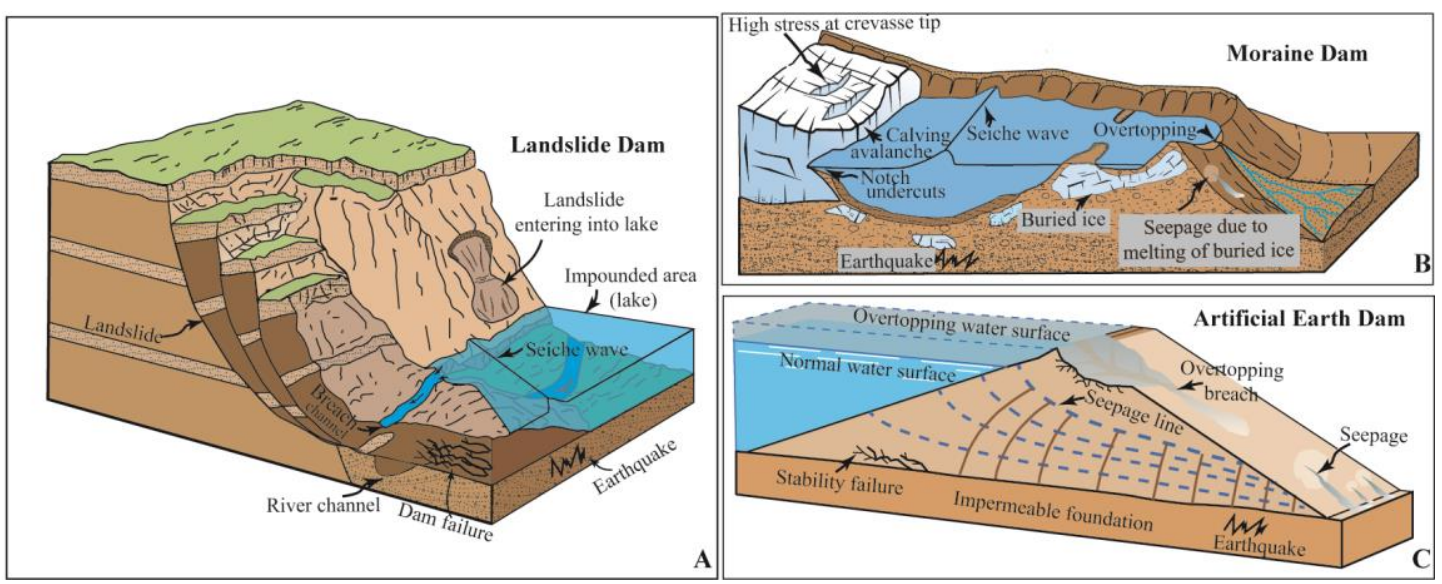

824

Figure 2.

825

826 

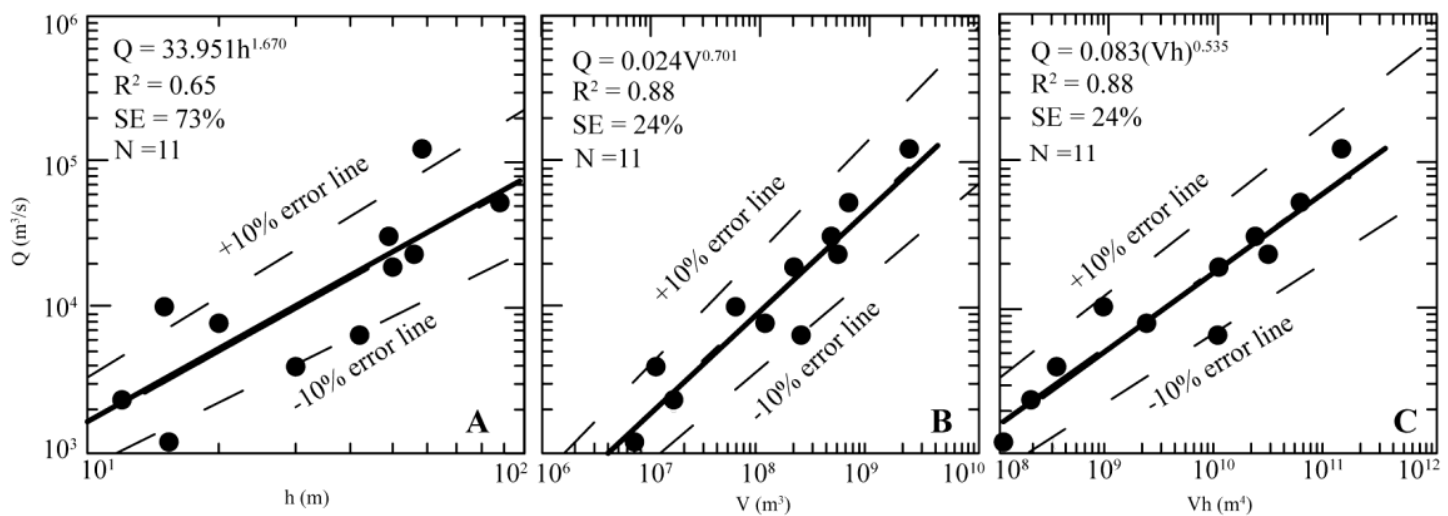

828

Figure 3.

829
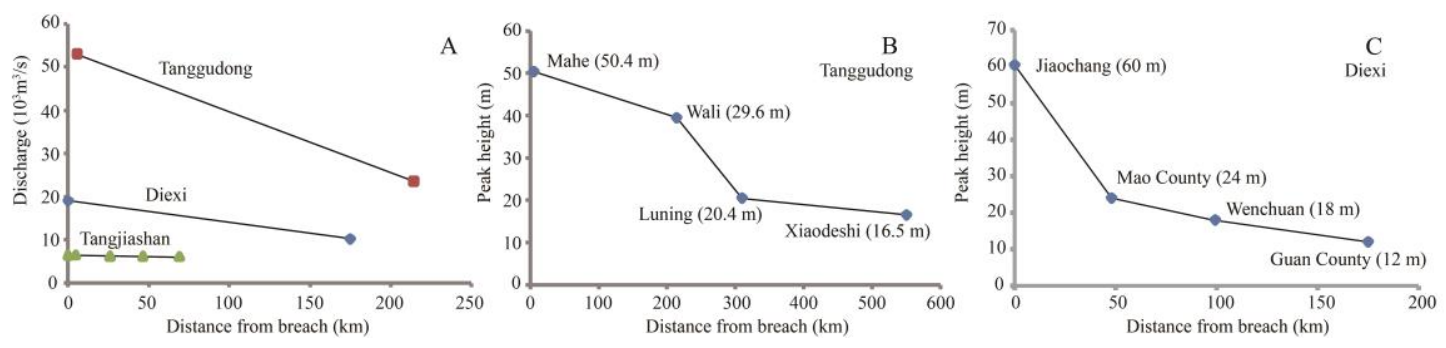

$831 \quad$ Figure 4.

832

833

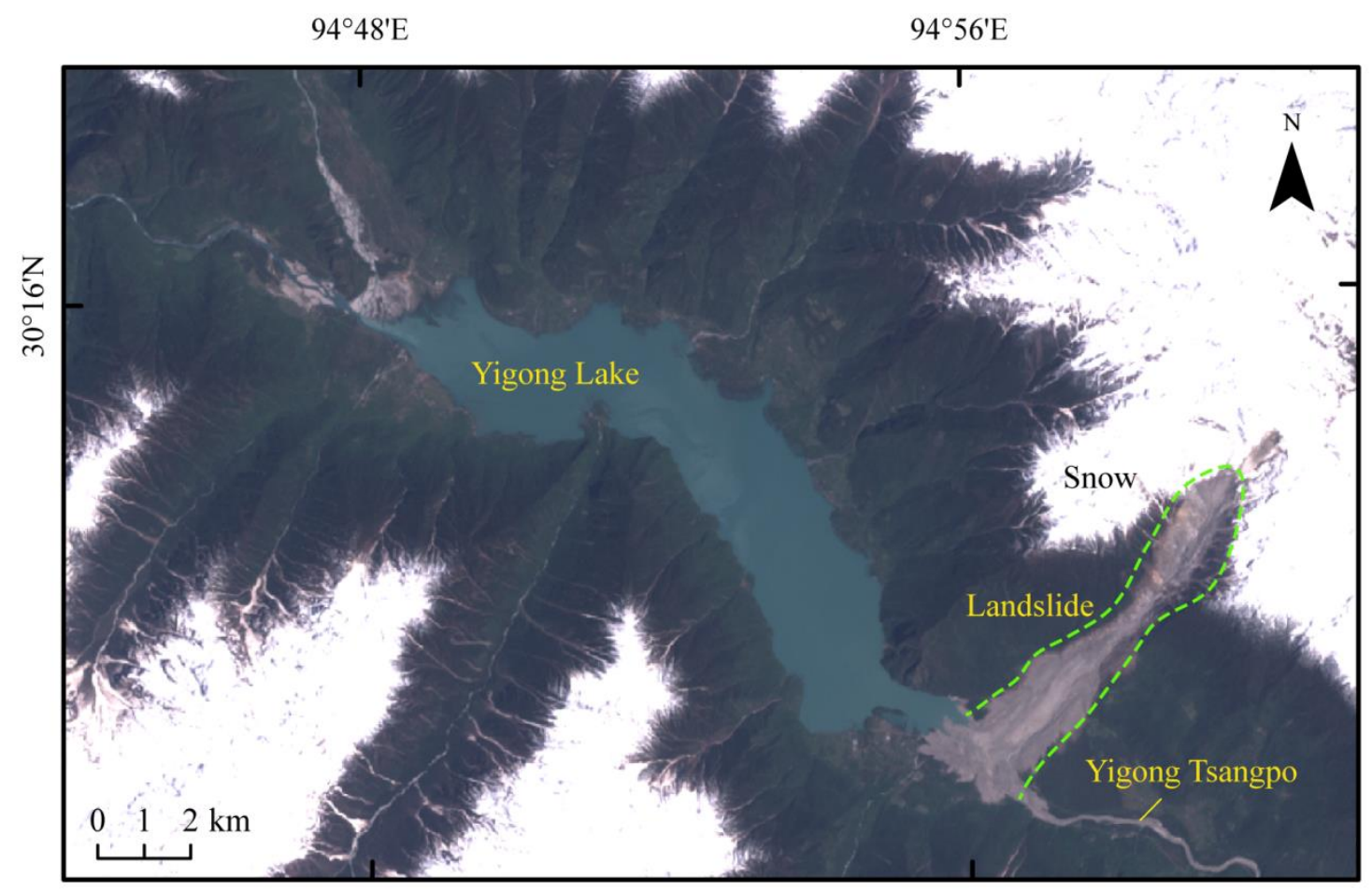

Figure 5. 


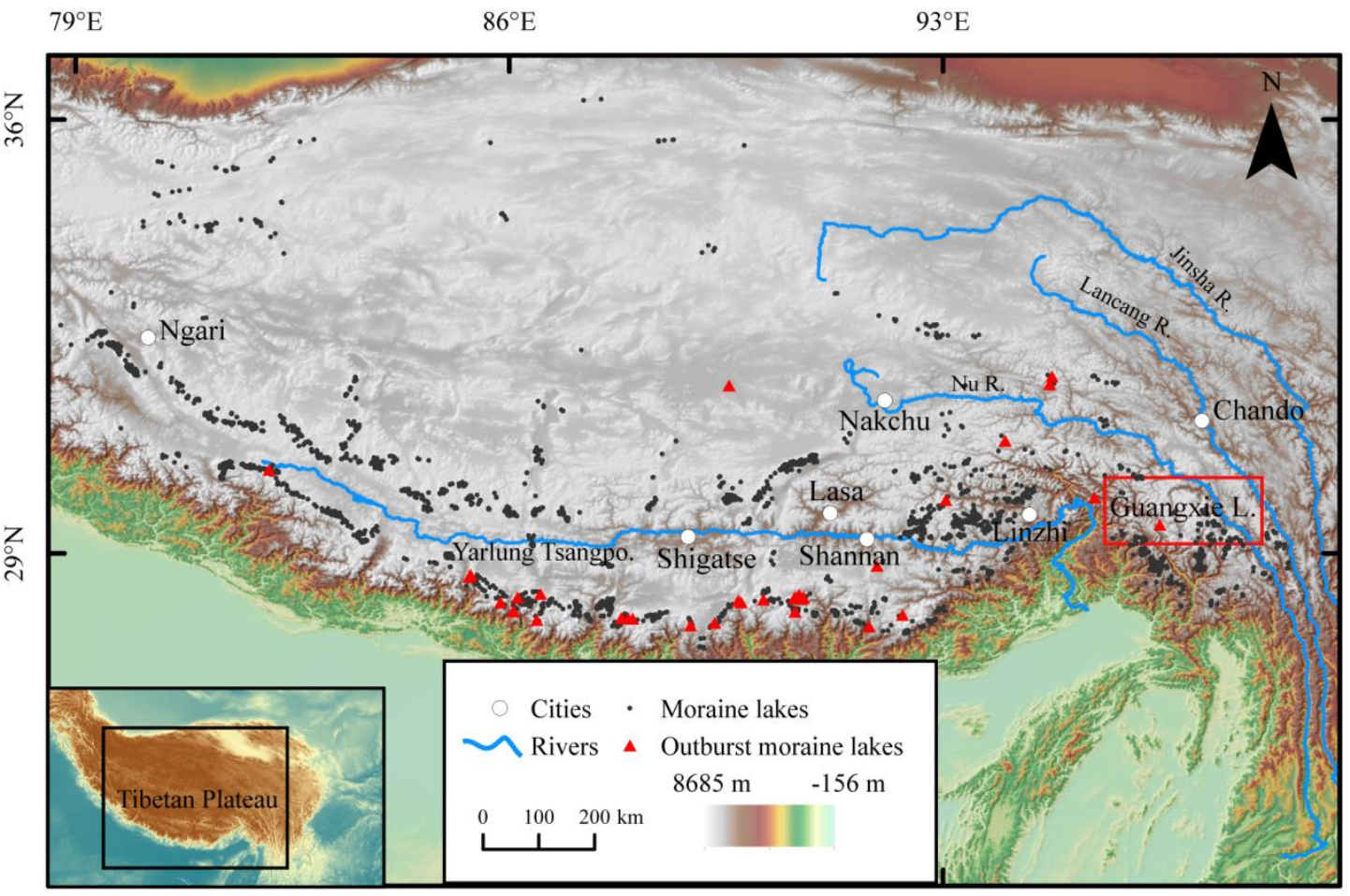

Figure 6.

839
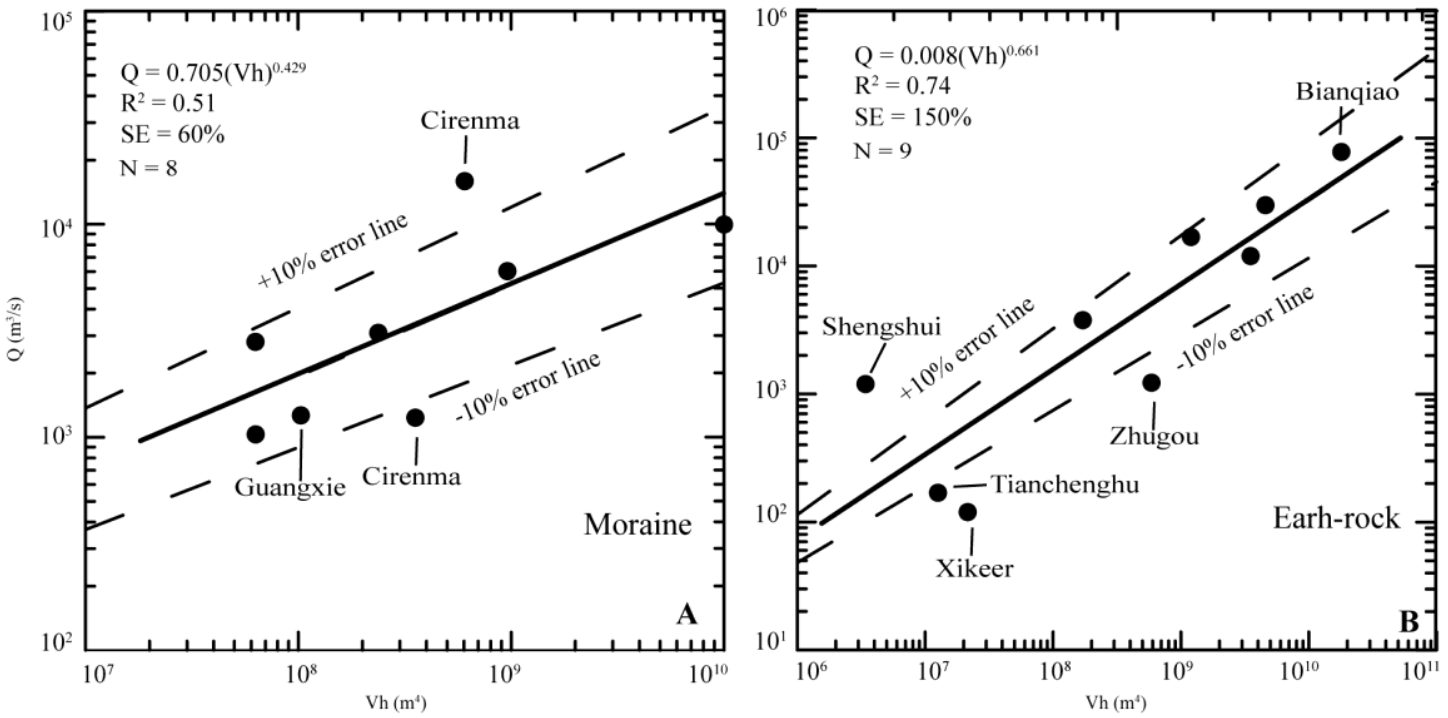

841

Figure 7. 


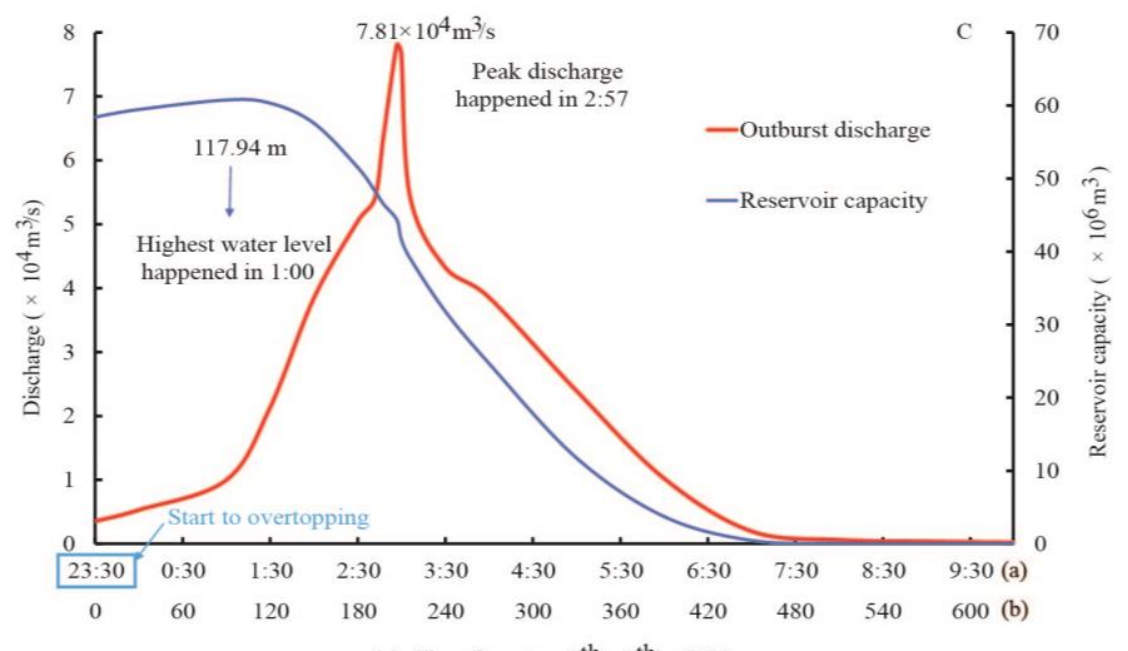

(a) Time fromAug. $7^{\text {th }}$ to $8^{\text {th }}$ in 1975

(b) Duration (min)

Figure 8.

845

846 


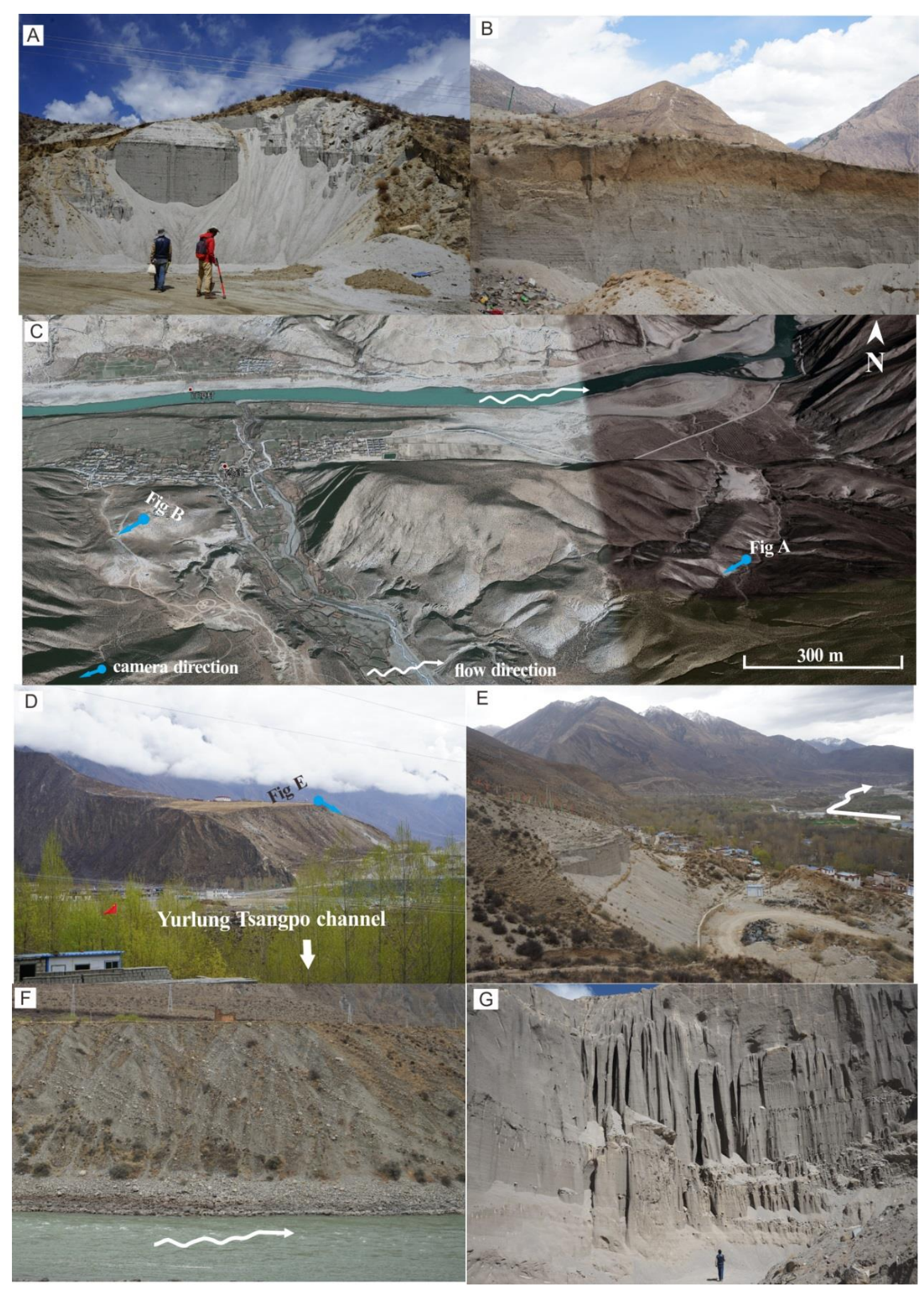

$848 \quad$ F igure 9.

849 
851 Table 1. The number of dams and outburst floods of each type dam we analyzed

\begin{tabular}{ccc}
\hline Types of dams & $\begin{array}{c}\text { Dam } \\
\text { number }\end{array}$ & $\begin{array}{c}\text { Number of regression } \\
\text { analysis }\end{array}$ \\
\hline Landslide dam & 287 & 11 \\
Artifical dam & 55 & 9 \\
Moraine dam & 33 & 8 \\
Glacier dam & 6 & - \\
rock-bound dam & 3 & - \\
Volcanogenic & & - \\
dam & 1 & \\
\hline
\end{tabular}

852

Table 2. Outburst floods from landslide dams in China

\begin{tabular}{|c|c|c|c|c|c|c|c|c|c|c|c|}
\hline $\begin{array}{l}\mathrm{N} \\
\mathrm{o}\end{array}$ & $\begin{array}{l}\text { Landsli } \\
\text { de }\end{array}$ & Date & Location & $\begin{array}{l}\text { Long. } \\
\text { (E) }\end{array}$ & $\begin{array}{l}\text { Lat. } \\
(\mathrm{N})\end{array}$ & $\begin{array}{c}\text { Vol. } \\
\text { relea } \\
\text { sed } \\
\left(10^{6}\right. \\
\left.\mathrm{m}^{3}\right)\end{array}$ & $\begin{array}{l}\text { Bre } \\
\text { ach } \\
\text { dep } \\
\text { th } \\
\text { (m) }\end{array}$ & $\begin{array}{c}\text { Peak } \\
\text { disc } \\
\text { harg } \\
\text { e } \\
(\mathrm{m} \\
3 / \mathrm{s})\end{array}$ & $\begin{array}{c}\text { Bloc } \\
\text { ked } \\
\text { river }\end{array}$ & $\begin{array}{l}\text { Induci } \\
\text { ng } \\
\text { factor }\end{array}$ & $\begin{array}{c}\text { Refe } \\
\text { renc } \\
\mathrm{e}\end{array}$ \\
\hline 1 & Diexi & $\begin{array}{c}1933 . \\
10.9\end{array}$ & $\begin{array}{c}\text { Mao } \\
\text { County, } \\
\text { Sichuan }\end{array}$ & $\begin{array}{l}103^{\circ} 41^{\prime} \\
20.84^{\prime \prime}\end{array}$ & $\begin{array}{c}32^{\circ} 01^{\prime} 4 \\
.74 "\end{array}$ & 202 & 50 & $\begin{array}{c}190 \\
75\end{array}$ & Min & $\begin{array}{c}\text { Earthq } \\
\text { uake }\end{array}$ & $\begin{array}{c}\text { Han et } \\
\text { al., 1999; } \\
\text { Nie et } \\
\text { al., } 2004\end{array}$ \\
\hline 2 & $\begin{array}{c}\mathrm{Da} \\
\text { Lake }\end{array}$ & $\begin{array}{c}1933 . \\
10.9\end{array}$ & $\begin{array}{c}\text { Mao } \\
\text { County, } \\
\text { Sichuan }\end{array}$ & $\begin{array}{c}103^{\circ} 41^{\prime} \\
31.75^{\prime \prime}\end{array}$ & $\begin{array}{c}32^{\circ} 03^{\prime} 2 \\
7.58^{\prime \prime \prime}\end{array}$ & 59 & 15 & $\begin{array}{c}102 \\
00\end{array}$ & Min & $\begin{array}{l}\text { Earthq } \\
\text { uake }\end{array}$ & $\begin{array}{l}\text { Chai et } \\
\text { al., } 1995\end{array}$ \\
\hline 3 & $\begin{array}{l}\text { Xiao } \\
\text { Lake }\end{array}$ & $\begin{array}{c}1986 . \\
6.15\end{array}$ & $\begin{array}{c}\text { Mao } \\
\text { County, } \\
\text { Sichuan }\end{array}$ & $\begin{array}{c}103^{\circ} 40^{\prime} \\
7.03^{\prime \prime}\end{array}$ & $\begin{array}{c}32^{\circ} 02^{\prime} 3 \\
0.32^{\prime \prime}\end{array}$ & 16 & 12 & $\begin{array}{c}234 \\
0\end{array}$ & Min & $\begin{array}{l}\text { Earthq } \\
\text { uake }\end{array}$ & $\begin{array}{c}\text { Han et } \\
\text { al., } 1999\end{array}$ \\
\hline 4 & $\begin{array}{c}\text { Tanggu } \\
\text { dong }\end{array}$ & $\begin{array}{c}1969 . \\
6.8\end{array}$ & $\begin{array}{l}\text { Yajiang, } \\
\text { Sichuan }\end{array}$ & $\begin{array}{c}101^{\circ} 00^{\prime} \\
53.60^{\prime \prime}\end{array}$ & $\begin{array}{c}30^{\circ} 02^{\prime 2} \\
0.89^{\prime \prime}\end{array}$ & 640 & 88 & $\begin{array}{c}530 \\
00\end{array}$ & $\begin{array}{c}\text { Yalo } \\
\text { ng }\end{array}$ & $\begin{array}{c}\text { Rainfa } \\
\quad 11\end{array}$ & $\begin{array}{l}\text { Wu and } \\
\text { Ran, } \\
1996\end{array}$ \\
\hline 5 & Yigong & $\begin{array}{c}2000 . \\
6.10\end{array}$ & $\begin{array}{l}\text { Bomi, } \\
\text { Tibet }\end{array}$ & $\begin{array}{c}94^{\circ} 52^{\prime} 4 \\
1.41^{\prime \prime}\end{array}$ & $\begin{array}{c}30^{\circ} 14^{\prime} 5 \\
.21 "\end{array}$ & $\begin{array}{c}230 \\
0\end{array}$ & $\begin{array}{l}58 . \\
39\end{array}$ & $\begin{array}{l}124 \\
000\end{array}$ & $\begin{array}{l}\text { Yig } \\
\text { ong } \\
\text { Tsan } \\
\text { gpo }\end{array}$ & $\begin{array}{l}\text { Meltin } \\
\text { g ice }\end{array}$ & $\begin{array}{c}\text { Lv et al., } \\
2002\end{array}$ \\
\hline 6 & $\begin{array}{c}\text { Xiaojia } \\
\text { qiao }\end{array}$ & $\begin{array}{c}2008 . \\
6.6\end{array}$ & $\begin{array}{c}\text { An } \\
\text { County, } \\
\text { Sichuan }\end{array}$ & $\begin{array}{c}104^{\circ} 16^{\prime} \\
39.93^{\prime \prime}\end{array}$ & $\begin{array}{c}31^{\circ} 38^{\prime} 5 \\
3.77^{\prime \prime}\end{array}$ & 7 & $\begin{array}{l}15 . \\
37\end{array}$ & $\begin{array}{c}120 \\
0\end{array}$ & $\begin{array}{l}\text { Cha } \\
\text { ping }\end{array}$ & $\begin{array}{c}\text { Earthq } \\
\text { uake }\end{array}$ & $\begin{array}{l}\text { Cheng et } \\
\text { al., } 2008\end{array}$ \\
\hline 7 & $\begin{array}{c}\text { Tangiia } \\
\text { shan }\end{array}$ & $\begin{array}{c}2008 . \\
6.10\end{array}$ & $\begin{array}{c}\text { Beichua } \\
n,\end{array}$ & $\begin{array}{c}104^{\circ} 26^{\prime} \\
3.41^{\prime \prime}\end{array}$ & $\begin{array}{c}31^{\circ} 50^{\prime} 3 \\
6.19^{\prime \prime}\end{array}$ & 235 & 42 & $\begin{array}{c}650 \\
0\end{array}$ & Qian & $\begin{array}{l}\text { Earthq } \\
\text { uake }\end{array}$ & $\begin{array}{l}\text { Chen et } \\
\text { al., } 2010\end{array}$ \\
\hline
\end{tabular}


Sichuan

\begin{tabular}{|c|c|c|c|c|c|c|c|c|c|c|c|}
\hline 8 & $\begin{array}{l}\text { Xiaoga } \\
\text { ngiian }\end{array}$ & $\begin{array}{c}2008 . \\
6.12\end{array}$ & $\begin{array}{l}\text { Mianzhu } \\
\quad, \\
\text { Sichuan }\end{array}$ & $\begin{array}{c}104^{\circ} 08^{\prime} \\
23.28^{\prime \prime}\end{array}$ & $\begin{array}{c}31^{\circ} 29^{\prime} 3 \\
4.87^{\prime \prime}\end{array}$ & 11 & 30 & $\begin{array}{c}395 \\
0\end{array}$ & $\begin{array}{c}\text { Mia } \\
\text { nyua } \\
\mathrm{n}\end{array}$ & $\begin{array}{l}\text { Earthq } \\
\text { uake }\end{array}$ & $\begin{array}{l}\text { Shi } \\
\text { et } \\
\text { al., } \\
2014\end{array}$ \\
\hline 9 & Baige & $\begin{array}{l}2018 . \\
10.13\end{array}$ & $\begin{array}{l}\text { Baiyu, } \\
\text { Sichuan }\end{array}$ & $\begin{array}{c}98^{\circ} \\
42^{\prime} 17.9 \\
8^{\prime \prime}\end{array}$ & $\begin{array}{c}31^{\circ} 04^{\prime} 5 \\
6.41^{\prime \prime}\end{array}$ & 110 & 20 & $\begin{array}{c}785 \\
0\end{array}$ & $\begin{array}{l}\text { Yan } \\
\text { gtze }\end{array}$ & & $\begin{array}{l}\text { ww } \\
\text { w.go } \\
\text { v.cn }\end{array}$ \\
\hline ) & Milin & $\begin{array}{l}2018 . \\
10.19\end{array}$ & $\begin{array}{l}\text { Milin, } \\
\text { Tibet }\end{array}$ & $\begin{array}{c}94^{\circ} \\
54^{\prime} 23.8 \\
9^{\prime \prime}\end{array}$ & $\begin{array}{c}29^{\circ} 42^{\prime} 2 \\
2.49^{\prime \prime}\end{array}$ & 510 & 56 & $\begin{array}{c}234 \\
00\end{array}$ & $\begin{array}{l}\text { Yarl } \\
\text { ung }\end{array}$ & & $\begin{array}{l}\text { w.m } \\
\text { wr.g } \\
\text { ov.c }\end{array}$ \\
\hline 1 & Baige & $\begin{array}{l}2018 . \\
11.12\end{array}$ & $\begin{array}{l}\text { Baiyu, } \\
\text { Sichuan }\end{array}$ & $\begin{array}{c}98^{\circ} \\
42^{\prime} 17.9 \\
8^{\prime \prime}\end{array}$ & $\begin{array}{c}31^{\circ} 04^{\prime} 5 \\
6.41^{\prime \prime}\end{array}$ & 445 & 49 & $\begin{array}{c}310 \\
00\end{array}$ & $\begin{array}{l}\text { Yan } \\
\text { gtze }\end{array}$ & & $\begin{array}{l}\text { sina. } \\
\text { com }\end{array}$ \\
\hline 1 & $\begin{array}{c}\text { Jinshax } \\
\text { ia }\end{array}$ & $\begin{array}{l}1920 \\
\text { BCE }\end{array}$ & $\begin{array}{l}\text { Xunhua, } \\
\text { Qinghai }\end{array}$ & $\begin{array}{c}102^{\circ} 40^{\prime} \\
34.38^{\prime \prime}\end{array}$ & $\begin{array}{c}35^{\circ} 50^{\prime} 0 \\
3.38^{\prime \prime}\end{array}$ & $\begin{array}{c}161 \\
00\end{array}$ & 135 & $\begin{array}{c}0.8 \\
\text { to } \\
5.1 \\
\times \\
10^{6 *}\end{array}$ & $\begin{array}{l}\text { Yell } \\
\text { ow }\end{array}$ & $\begin{array}{l}\text { Earthq } \\
\text { uake }\end{array}$ & $\begin{array}{l}\mathrm{Wu} \\
\text { et al. } \\
(201 \\
6)\end{array}$ \\
\hline 1 & $\begin{array}{c}\text { Baimak } \\
\text { ou }\end{array}$ & $\begin{array}{l}7.5 \\
\mathrm{ka}\end{array}$ & $\begin{array}{l}\text { Wuding, } \\
\text { Yunnan }\end{array}$ & $\begin{array}{c}102^{\circ} 04^{\prime} \\
36.54^{\prime \prime}\end{array}$ & $\begin{array}{c}25^{\circ} 58^{\prime} 4 \\
9.94 "\end{array}$ & $\begin{array}{c}624 \\
0\end{array}$ & 106 & $\begin{array}{c}8.2 \\
\times \\
10^{4 *}\end{array}$ & $\begin{array}{l}\text { Yan } \\
\text { gtze }\end{array}$ & & $\begin{array}{l}\text { Liu } \\
\text { et al. } \\
\text { (201 } \\
8)\end{array}$ \\
\hline
\end{tabular}

*The discharge is estimated by empirical formulas.

Table 3. Moraine-dammed lake outburst floods in China

\begin{tabular}{|c|c|c|c|c|c|c|c|}
\hline No. & Name & Date & Location & $\begin{array}{l}\text { Latitude } \\
\text { (N) }\end{array}$ & $\begin{array}{l}\text { Longitude } \\
\text { (E) }\end{array}$ & $\begin{array}{l}\text { Elevation } \\
\quad(\mathrm{m})\end{array}$ & $\begin{array}{c}\text { Volume } \\
\text { released } \\
\quad\left(10^{6}\right. \\
\left.\mathrm{m}^{3}\right)\end{array}$ \\
\hline 1 & Taа & 1935.8 .28 & Nielamu, Tibet & $28^{\circ} 17^{\prime} 34.03^{\prime \prime}$ & $86^{\circ} 7{ }^{\prime} 53.76^{\prime \prime}$ & 5245 & 6.3 \\
\hline 2 & Sanwang & 1954.7 .16 & Kangma, Tibet & $28^{\circ} 13^{\prime} 59.67^{\prime \prime}$ & $90^{\circ} 6^{\prime} 16.81^{\prime \prime}$ & 5150 & 250 \\
\hline 3 & Longda & 1964.08 .25 & Jilong, Tibet & $28^{\circ} 37^{\prime} 15.37^{\prime \prime}$ & $85^{\circ} 20^{\prime} 55.24^{\prime \prime}$ & 5460 & 10.8 \\
\hline 4 & Jilai & 1964.09.21 & Dingjie, Tibet & $27^{\circ} 57^{\prime} 52.06^{\prime \prime}$ & $87^{\circ} 48^{\prime} 50.44^{\prime \prime}$ & 5271 & 23.4 \\
\hline 5 & Damen & 1964.09 .26 & Gongbujiangda, & $29^{\circ} 52^{\prime} 6.14^{\prime \prime}$ & $93^{\circ} 2^{\prime} 26.22^{\prime \prime}$ & 5210 & 3.7 \\
\hline
\end{tabular}


Tibet

6

Cirenma

1981.7.11

Nielamu, Tibet

$28^{\circ} 4^{\prime} 0.55^{\prime \prime}$

$86^{\circ} 3{ }^{\prime} 59.47^{\prime \prime}$

4660

18.9

7

Guangxie

1988.7.15

Bomi, Tibet

$29^{\circ} 27^{\prime} 51.97^{\prime \prime} \quad 96^{\circ} 30^{\prime} 7.79^{\prime \prime}$

3816

Data from: Liu et al., 2008; Liu, 2006a; Xu et al., 1989; Yao et al., 2014.

Table 4. Moraine-dammed outburst events with debris flows

\begin{tabular}{|c|c|c|c|}
\hline Number & Name & Date & $\begin{array}{l}\text { Description of glacial lake } \\
\text { outburst debris flow }\end{array}$ \\
\hline 1 & Sangwang & 1954.7 .16 & $\begin{array}{l}\text { It is a less viscosity debris flows with discharge } \\
\text { of } 10000 \mathrm{~m}^{3} / \mathrm{s} \text {, More than } 20,000 \text { people were } \\
\text { affected, and about } 400 \text { died. Some } 5733 \text { ha of } \\
\text { farmland was submerged and } 866.7 \text { ha of } \\
\text { farmland was destroyed. }\end{array}$ \\
\hline 2 & Jilai & 1964.09.21 & $\begin{array}{l}\text { It form into less viscosity and viscous debris } \\
\text { flows with discharge of } 6048 \mathrm{~m}^{3} / \mathrm{s} \text {, It washed } \\
\text { away } 12 \text { trucks and damaged } 20 \mathrm{~km} \text { of road. }\end{array}$ \\
\hline 3 & Cirenma & 1964/1981.7.11 & $\begin{array}{l}\text { The debris flows with a peak depth of } 25 \mathrm{~m} \\
\text { smashed the Zhongni highway road and bridge, } \\
\text { rushed out } 1.2 \text { million } \mathrm{m}^{3} \text { of mud and sand and } \\
\text { blocked the river }\end{array}$ \\
\hline 4 & Guangxie & 1988.7 .15 & $\begin{array}{l}\text { Large-scale debris flows swept through Neimidui } \\
\text { village, into the main river and blocked the dam. } \\
\text { The Sichuan-Tibet highway was completely } \\
\text { destroyed along a length of } 21.57 \mathrm{~km} \text {. }\end{array}$ \\
\hline 5 & Jialong & 2002.05.23/06.29 & $\begin{array}{l}\text { It form into less viscosity and viscous debris } \\
\text { flows with discharge of } 2.36 \times 10^{7} \mathrm{~m}^{3} / \mathrm{s} \text {, and one } \\
\text { reinforced concrete bridge, } 20.5 \mathrm{mu} \text { of farmland, } \\
50 \mathrm{mu} \text { of grassland, } 4 \text { houses, } 1 \mathrm{cow} \text { were } \\
\text { washed away, and the economic loss was about } \\
3.05 \text { million yuan. }\end{array}$ \\
\hline
\end{tabular}

Table 5. Number of dam break events for different size dams in China since 1954 


\begin{tabular}{cccccc}
\hline Period & Large & Medium & Small & Total & $\%$ \\
\hline $1954-1960$ & & 64 & 285 & 349 & 9.9 \\
$1961-1970$ & & 27 & 563 & 590 & 16.8 \\
$1971-1980$ & 2 & 26 & 2010 & 2038 & 57.9 \\
$1981-1990$ & & 4 & 260 & 264 & 7.5 \\
$1991-2000$ & & 2 & 224 & 226 & 6.4 \\
$2001-2010$ & & 4 & 44 & 48 & 1.4 \\
$2011-2012$ & & 0 & 5 & 5 & 0.1 \\
\hline Total & 2 & 127 & 3391 & 3520 & 100 \\
\hline
\end{tabular}

867

868

869

870

871

Data from: Zhang et al. (2014). Large reservoirs have a capacity of $>100$ million $\mathrm{m}^{3}$; medium reservoirs have a capacity from 10 million to 100 million $\mathrm{m}^{3}$; and small reservoirs have a capacity have a capacity of $<10$ million $\mathrm{m}^{3}$.

Table 6. Number of outburst events by dam type

\begin{tabular}{|c|c|c|c|c|c|}
\hline \multicolumn{2}{|c|}{ No. } & \multicolumn{2}{|c|}{ Primary classification } & Number of dams & $\%$ \\
\hline 1 & & \multicolumn{2}{|c|}{ Concrete dam } & 12 & 0.34 \\
\hline 2 & & \multicolumn{2}{|c|}{ Masonry dam } & 34 & 0.97 \\
\hline 3 & & \multicolumn{2}{|c|}{ Earth-rock dam } & 3253 & 93 \\
\hline \multirow{6}{*}{3} & (1) & \multirow{6}{*}{ Sub-types } & $\begin{array}{l}\text { Homogeneous } \\
\text { earth dam }\end{array}$ & 3002 & 85.28 \\
\hline & (2) & & Clay dike dam & 11 & 0.31 \\
\hline & (3) & & Clay core dam & 183 & 5.23 \\
\hline & (4) & & $\begin{array}{c}\text { Earth and stone } \\
\text { dam }\end{array}$ & 19 & 0.54 \\
\hline & (5) & & Other & 2 & 0.06 \\
\hline & (6) & & Unknown & 36 & 1.03 \\
\hline 4 & & \multicolumn{2}{|c|}{ Rockfill dam } & 32 & 0.91 \\
\hline 5 & & \multicolumn{2}{|c|}{$\begin{array}{l}\text { Others (including mixed } \\
\text { dams) }\end{array}$} & 5 & 0.14 \\
\hline 6 & & \multicolumn{2}{|c|}{ Unknown } & 160 & 4.63 \\
\hline
\end{tabular}

Data from: Zhang et al. (2014)

Table 7. Reasons for failure of constructed dams in China

\begin{tabular}{|c|c|c|}
\hline No. & Reason & $\%$ \\
\hline \multirow[t]{3}{*}{1} & Overtopping & 51.5 \\
\hline & (1) insufficient discharge capacity & 42 \\
\hline & (2) flood protection standard & 9.5 \\
\hline \multirow[t]{5}{*}{2} & Piping & 29.1 \\
\hline & (1) dam leakage & 22.7 \\
\hline & (2) seepage & 1.3 \\
\hline & (3) spillway leakage & 0.6 \\
\hline & (4) hole leakage & 4.5 \\
\hline 3 & Structural instability & 9.4 \\
\hline 4 & Mismanagement & 4.2 \\
\hline
\end{tabular}


876

877 


\begin{tabular}{|c|c|c|c|c|c|c|c|c|c|c|}
\hline No. & Name & Date & Location & $\begin{array}{l}\text { Latitude } \\
\text { (E) }\end{array}$ & $\begin{array}{l}\text { Longitude } \\
\text { (N) }\end{array}$ & $\begin{array}{l}\text { Volume } \\
\text { released } \\
\left(10^{6} \mathrm{~m}^{3}\right) \\
\end{array}$ & $\begin{array}{c}\text { peak } \\
\text { discharge } \\
\left(\mathrm{m}^{3} / \mathrm{s}\right)\end{array}$ & $\begin{array}{c}\text { breach } \\
\text { depth } \\
(\mathrm{m})\end{array}$ & river & $\begin{array}{c}\text { Dam failure } \\
\text { reason }\end{array}$ \\
\hline 1 & Deliji & 1962.7.26 & $\begin{array}{l}\text { Chaoyang, } \\
\text { Liaoning }\end{array}$ & $41^{\circ} 24^{\prime} 23.61^{\prime \prime}$ & $120^{\circ} 16 ' 39.64 "$ & 51 & 16900 & 23.5 & $\begin{array}{c}\text { Laohushan } \\
\text { River }\end{array}$ & $\begin{array}{l}\text { Continuous } \\
\text { rainfall }\end{array}$ \\
\hline 2 & Mahe & 1963.8 .4 & Neiqiu, Hebei & $35^{\circ} 12^{\prime} 41.20^{\prime \prime}$ & $117^{\circ} 12^{\prime} 52.09^{\prime \prime}$ & 24.45 & 7500 & 19.9 & $\begin{array}{c}\text { Xiaobai } \\
\text { River }\end{array}$ & $\begin{array}{c}\text { Sudden and } \\
\text { continuous } \\
\text { rain }\end{array}$ \\
\hline 3 & Hengjiang & 1970.09 .15 & Jiexi,Guangdong & $23^{\circ} 29^{\prime} 10.27^{\prime \prime}$ & $115^{\circ} 48^{\prime} 5.79^{\prime \prime}$ & 77.84 & 12000 & 45 & $\begin{array}{c}\text { Hengjiang } \\
\text { River }\end{array}$ & $\begin{array}{l}\text { Typhoon } \\
\text { rainstorm }\end{array}$ \\
\hline 4 & Zhugou & 1975.8 .7 & Queshan, Henan & $32^{\circ} 48^{\prime} 12.88^{\prime \prime}$ & $113^{\circ} 43^{\prime} 26.09^{\prime \prime}$ & 28.642 & 1177 & 21.5 & $\begin{array}{l}\text { Zhentou } \\
\text { River }\end{array}$ & $\begin{array}{l}\text { Continual } \\
\text { rainstorm }\end{array}$ \\
\hline 5 & Banqiao & 1975.8.7 & Qingyang, Henan & $32^{\circ} 59^{\prime} 19.43^{\prime \prime}$ & $113^{\circ} 37^{\prime} 7.16^{\prime \prime}$ & 608 & 78100 & 29.54 & Nv River & $\begin{array}{l}\text { Continual } \\
\text { rainstorm }\end{array}$ \\
\hline 6 & Shimantan & 1975.8 .8 & Wugang, Henan & $33^{\circ} 16^{\prime} 51.64^{\prime \prime}$ & $113^{\circ} 33^{\prime} 17.68^{\prime \prime}$ & 167 & 30000 & 27.4 & Gun River & $\begin{array}{l}\text { Continual } \\
\text { rainstorm }\end{array}$ \\
\hline 7 & Danghe & 1979.7.27 & Dunhuang, Gangsu & $39^{\circ} 57^{\prime} 7.92^{\prime \prime}$ & $94^{\circ} 19^{\prime} 52.80^{\prime \prime}$ & 18.7 & 2500 & 25 & $\begin{array}{l}\text { Dang } \\
\text { River }\end{array}$ & $\begin{array}{c}\text { Continuous } \\
\text { rainfall }\end{array}$ \\
\hline 8 & Xiaozhaizi & 1998.3.8 & $\begin{array}{c}\text { Danjiangkou, } \\
\text { Hubei }\end{array}$ & $32^{\circ} 32^{\prime} 21.31^{\prime \prime}$ & $111^{\circ} 3^{\prime} 10.96^{\prime \prime}$ & 0.2 & 840 & 10.3 & $\begin{array}{c}\text { Guanshan } \\
\text { River }\end{array}$ & $\begin{array}{l}\text { Dam design } \\
\text { error }\end{array}$ \\
\hline 9 & Shengshui & 1998.7.27 & $\begin{array}{l}\text { Arongqi, } \\
\text { Neimenggu }\end{array}$ & $48^{\circ} 16^{\prime} 12.95^{\prime \prime}$ & ${ }^{42} 123^{\circ} 26^{\prime} 19.81^{\prime \prime}$ & 2.625 & 1200 & 1.3 & $\begin{array}{l}\text { Tangwang } \\
\text { gully }\end{array}$ & $\begin{array}{l}\text { Continuous } \\
\text { rainfall }\end{array}$ \\
\hline 10 & Xikeer & 2002.3.4 & Kashi, Xinjiang & $39^{\circ} 47^{\prime} 56.17^{\prime \prime}$ & $77^{\circ} 20^{\prime} 12.89^{\prime \prime}$ & 4.3 & 120 & 5 & Kezi River & Earthquake \\
\hline
\end{tabular}




\begin{tabular}{|c|c|c|c|c|c|c|c|c|c|c|}
\hline 11 & Wuhaohe & 2003.7 .25 & $\begin{array}{l}\text { Lingcheng, } \\
\text { Neimenggu }\end{array}$ & $40^{\circ} 27^{\prime} 6.05^{\prime \prime}$ & $112^{\circ} 27^{\prime} 41.93^{\prime \prime}$ & 10.09 & 3790 & 16.93 & $\begin{array}{l}\text { Wuhao } \\
\text { River }\end{array}$ & $\begin{array}{c}\text { heavy } \\
\text { rainfall }\end{array}$ \\
\hline 12 & Tianchenghu & 2005.4 .30 & Gaotai, Gangsu & $39^{\circ} 42^{\prime} 43.23^{\prime \prime}$ & $99^{\circ} 33^{\prime} 9.73^{\prime \prime}$ & 2.8 & 170 & 4.5 & $\begin{array}{l}\text { Black } \\
\text { River }\end{array}$ & $\begin{array}{l}\text { poor design, } \\
\text { Construction } \\
\text { and } \\
\text { management } \\
\text { of dam }\end{array}$ \\
\hline 13 & Majingao & 2007.7 .26 & Danzhai, Guizhou & $26^{\circ} 5^{\prime} 59.08^{\prime \prime}$ & $107^{\circ} 57^{\prime} 31.83^{\prime \prime}$ & 6.76 & 14000 & 34 & $\begin{array}{c}\text { Paidiao } \\
\text { River }\end{array}$ & $\begin{array}{c}\text { Rock-avalan } \\
\text { che }\end{array}$ \\
\hline
\end{tabular}

879

Data from: Zhang et al., 2014. Among them, 1, 2, 3, 5, 6, 7, 8,11 and 13 are outburst floods from earth-rock dams. 
886 Table 9. Characteristics of volcanic lakes in China

\begin{tabular}{|c|c|c|c|c|c|c|}
\hline No. & Name & Location & $\begin{array}{l}\text { Longitude } \\
\text { (E) }\end{array}$ & $\begin{array}{l}\text { Latitude } \\
\text { (N) }\end{array}$ & $\begin{array}{c}\text { Lake } \\
\text { elevation } \\
\text { (m) }\end{array}$ & $\begin{array}{l}\text { Maximum } \\
\text { water depth } \\
\text { (m) }\end{array}$ \\
\hline & Changbai & & & & & \\
\hline & Mountain & & & & & \\
\hline 1 & Tianchi & Baishan, Jilin & $128^{\circ} 3^{\prime} 14.10^{\prime \prime}$ & $42^{\circ} 1 ' 27.88$ & 2189 & 373 \\
\hline & $\begin{array}{l}\text { Five-linke } \\
\text { d-great-po }\end{array}$ & Wudalianchi, & & & & \\
\hline 2 & ol & $\begin{array}{c}\text { Heilongiiang } \\
\text { Ningan, }\end{array}$ & $126^{\circ} 14^{\prime} 8.49^{\prime \prime}$ & $48^{\circ} 43^{\prime} 55.43^{\prime \prime}$ & 275 & 31 \\
\hline 3 & Jing po & Heilongiiang & $128^{\circ} 51^{\prime} 30.38^{\prime \prime}$ & $43^{\circ} 48^{\prime} 22.36^{\prime \prime}$ & 243 & 74 \\
\hline 4 & $\begin{array}{c}\text { Dalong } \\
\text { Sanjiaolo }\end{array}$ & Huinan, Jilin & $126^{\circ} 23^{\prime} 20.06^{\prime \prime}$ & $42^{\circ} 20^{\prime} 1.85^{\prime \prime}$ & 625 & 96 \\
\hline 5 & ng & Huinan, Jilin & $126^{\circ} 25^{\prime} 54.94 "$ & $42^{\circ} 22^{\prime} 3.28^{\prime \prime}$ & 722 & 76 \\
\hline 6 & Donglong & Huinan, Jilin & $126^{\circ} 30^{\prime} 40.09^{\prime \prime}$ & $42^{\circ} 25^{\prime} 30.09^{\prime \prime}$ & 599 & 114 \\
\hline 7 & Nanlong & Huinan, Jilin & $126^{\circ} 28^{\prime} 41.53^{\prime \prime}$ & $42^{\circ} 24^{\prime} 51.08^{\prime \prime}$ & 724 & $\mathrm{~N} / \mathrm{D}$ \\
\hline 8 & Xiaolong & Huinan, Jilin & $126^{\circ} 21^{\prime} 31.41^{\prime \prime}$ & $42^{\circ} 17^{\prime} 57.70^{\prime \prime}$ & 655 & N/D \\
\hline 9 & $\begin{array}{l}\text { Sihailong } \\
\text { Longquan }\end{array}$ & Jingyu, Jilin & 1263'1.96" & $42^{\circ} 17^{\prime} 8.66^{\prime \prime}$ & 791 & N/D \\
\hline 10 & long & Jingyu, Jilin & $126^{\circ} 36^{\prime} 12.65^{\prime \prime}$ & $42^{\circ} 25^{\prime} 4.26^{\prime \prime}$ & 617 & 91 \\
\hline
\end{tabular}

887 Data from: Fan et al., 2003; Liu, 1999; Liu et al., 1997; Liu et al., 2017; Wei et al., 888 2003; Wei et al., 2004.

889

890 